\title{
Bone Morphogenetic Proteins
}

\author{
Takenobu Katagiri ${ }^{1}$ and Tetsuro Watabe ${ }^{2}$ \\ ${ }^{1}$ Division of Pathophysiology, Research Center for Genomic Medicine, Saitama Medical University, Hidaka-shi, \\ Saitama 350-1241, Japan \\ ${ }^{2}$ Section of Biochemistry, Department of Bio-Matrix, Graduate School of Medical and Dental Sciences, Tokyo \\ Medical and Dental University, Bunkyo-ku, Tokyo 113-8549, Japan \\ Correspondence: katagiri@saitama-med.ac.jp; t-watabe@umin.ac.jp
}

Bone morphogenetic proteins (BMPs), originally identified as osteoinductive components in extracts derived from bone, are now known to play important roles in a wide array of processes during formation and maintenance of various organs including bone, cartilage, muscle, kidney, and blood vessels. BMPs and the related "growth and differentiation factors" (GDFs) are members of the transforming growth factor $\beta$ (TGF- $\beta$ ) family, and transduce their signals through type I and type II serine-threonine kinase receptors and their intracellular downstream effectors, including Smad proteins. Furthermore, BMP signals are finely tuned by various agonists and antagonists. Because deregulation of the BMPactivity at multiple steps in signal transduction is linked to a wide variety of human diseases, therapeutic use of activators and inhibitors of BMP signaling will provide potential avenues for the treatment of the human disorders that are caused by hypo- and hyperactivation of BMP signals, respectively.

$\mathrm{T}_{\mathrm{h}}^{\mathrm{h}}$ he bone morphogenetic protein (BMP) family of ligands plays important roles in a multitude of processes during embryonic development and adult homeostasis by regulating cellular lineage commitment, morphogenesis, differentiation, proliferation, and apoptosis of various types of cells throughout the body. In this review, we describe biochemical properties and biological activities of BMP family members in development and diseases.

Although BMPs are now known to be multifunctional cytokines identified both in vertebrates and invertebrates, they were first discovered as proteins that induce ectopic bone formation. In 1889, Senn found that aseptic bone cavities can be healed by decalcified bone
(Senn 1889). In 1965, Urist reported that demineralized bone matrix implanted in muscular tissues induces ectopic formation of cartilage and bone tissues with bone marrow (Urist 1965). These findings postulated the presence of bioactive factor(s) in the demineralized bone matrix responsible for inducing bone formation. The factor(s) responsible for ectopic bone formation was named "bone morphogenetic protein," because this activity was abolished by digestion with trypsin, a typical protease (Urist and Strates 1971). However, the identity of the BMP activity remained elusive until Wang and colleagues reported the isolation of BMP activity from extracts of bovine bone as a single gel band followed by sequencing the pep-

Editors: Rik Derynck and Kohei Miyazono

Additional Perspectives on The Biology of the TGF- $\beta$ Family available at www.cshperspectives.org

Copyright (C) 2016 Cold Spring Harbor Laboratory Press; all rights reserved; doi: 10.1101/cshperspect.a021899

Cite this article as Cold Spring Harb Perspect Biol 2016;8:a021899 
tides obtained from trypsin digestion of the band (Wang et al. 1988). Subsequently, Wozney and colleagues (1988) cloned cDNAs for human BMP-1 through BMP-4 using the peptide sequence information obtained. Although BMP1 was found to be a novel metalloproteinase, BMP-2, -3 , and -4 were novel members of the transforming growth factor $\beta$ (TGF- $\beta$ ) family. The corresponding recombinant BMP proteins, including BMP-1, were capable of inducing formation of cartilage or bone in vivo. Subsequently, the coding sequences of additional BMPs were cloned based on amino acid sequence homology (Celeste et al. 1990; Özkaynak et al. 1990; Sampath et al. 1990). Although the bone-inducing activity is unique to BMPs among the TGF- $\beta$ family members (Sampath and Reddi 1983), it was later shown that BMPs have many other biological activities.

\section{BIOCHEMICAL PROPERTIES OF BMPS AND THEIR INTRACELLULAR SIGNALING}

As mentioned above, the name "bone morphogenetic protein" was originally assigned for a unique activity in demineralized bone matrix, which induces heterotopic bone formation in nonskeletal tissues, such as skeletal muscle and subcutaneous tissue (Urist 1965). However, the name "BMP" does not infer the biological activity of all BMP members of the TGF- $\beta$ family, because they were cloned by homology of DNA or amino acid sequences rather than biological activity. The heterotopic bone-inducing activity in the implantation assay in nonskeletal soft tissues was confirmed for several BMPs and "growth and differentiation factors" (GDFs), but does not apply to TGF- $\beta$ s, activins, and even several BMPs and GDFs in the TGF- $\beta$ family, as will be discussed below. The osteogenic and non-osteogenic activities among the TGF$\beta$ family members depend on the structures, binding receptors, intracellular signaling molecules, and target genes.

\section{Classification of BMPs}

More than a dozen BMPs have been identified in vertebrates, and have highly conserved struc- tures that are shared by the members of the TGF- $\beta$ family. Because BMP family members were identified using multiple approaches, some were described with different names such as cartilage-derived morphogenetic proteins (CDMPs), GDFs, osteogenic proteins (OPs), osteogenin, and Vg-related (Vgr), as illustrated in Figure 1. In this article, only the terms "BMP" and "GDF" are used to avoid confusion. Based on structural homology, the BMP family members can be further classified into several subgroups, including the BMP-2/-4 group, BMP$5 /-6 /-7$ (OP-1)/-8 group, BMP-9/-10 group, and BMP-12/-13/-14 (GDF-5/-6/-7) group (Fig. 1). Among BMP family members, only BMP-1 has a metalloproteinase structure and acts as a carboxy-terminal propeptidase for type I collagen (Kessler et al. 1996). BMP family members are found in invertebrates such as decapentaplegic (Dpp), 60A/ glass bottom boat (Gbb), and Screw in Drosophila, and DAF-7 in Caenorhabditis elegans. Interestingly, Drosophila Dpp and 60A/Gbb, which are structurally similar to BMP-2 and -4 and BMP- 6 and -7, respectively, induced ectopic bone formation in rats (Sampath et al. 1993), and human BMP-4 rescued the phenotype resulting from Dpp mutation in Drosophila (Padgett et al. 1993), suggesting that the biological activities of BMPs are highly conserved between flies and humans.

\section{Structures and Processing of BMPs}

Similar to other members of the TGF- $\beta$ family, BMP family members are synthesized as inactive large pre-pro-polypeptides that contain signal peptides at their amino termini and mature polypeptides at the carboxyl termini, separated by pro-domains (Xiao et al. 2007). The BMP-4 precursor protein is cleaved by furin, a pro-protein convertase, to liberate the mature BMP polypeptide (Nelsen and Christian 2009). These mature BMP monomers contain seven cysteines, six of which form intramolecular disulfide bonds. The remaining seventh cysteine residue is involved in the dimerization with another BMP monomer through a covalent disulfide bond, resulting in a biologically active dimeric ligand for BMP receptor activation 


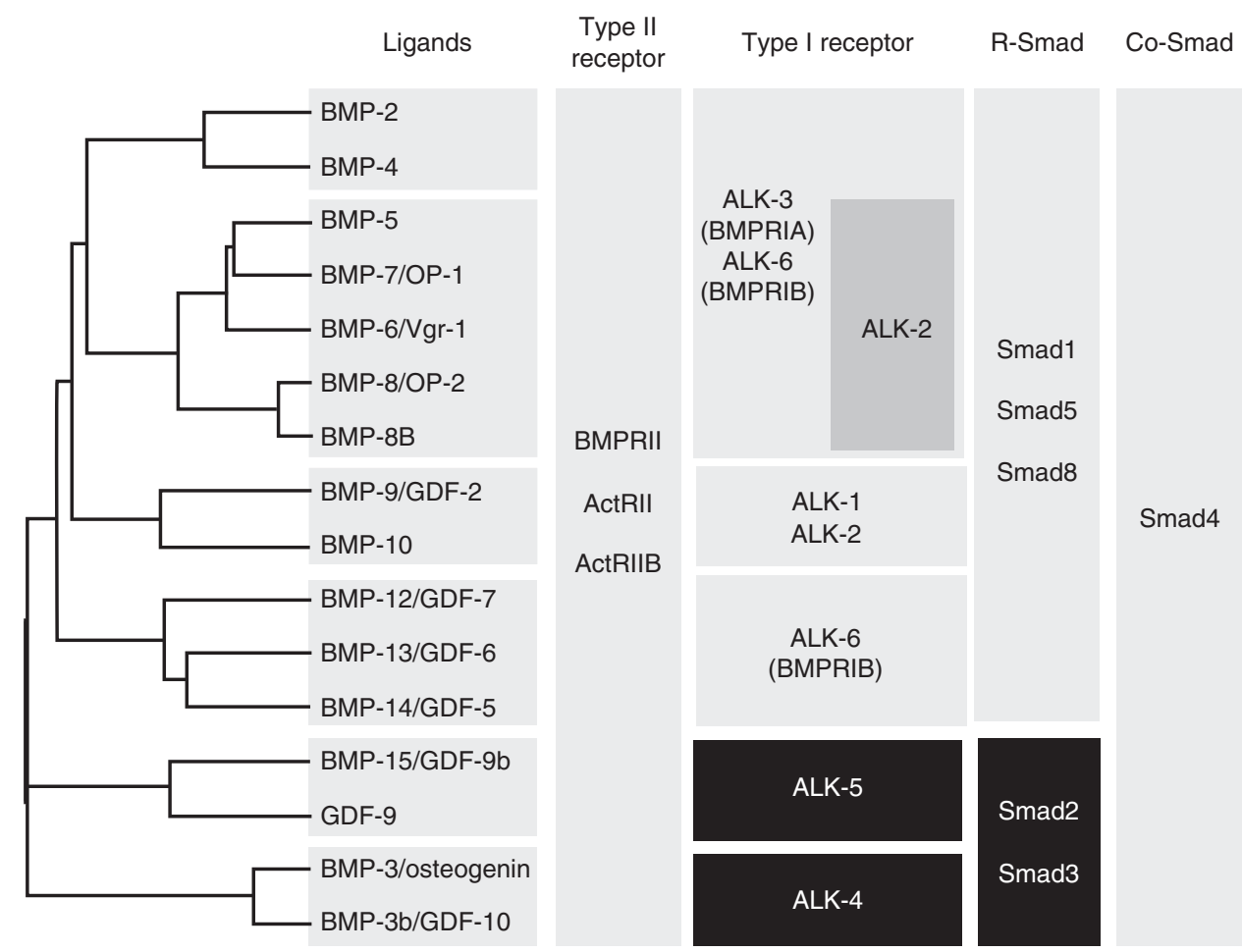

Figure 1. Relationships between bone morphogenetic protein/growth and differentiation factor (BMP/GDF) ligands, type II receptors, type I receptors, and Smad proteins in signal transduction. BMP-1 is a metalloproteinase and is not a member of the transforming growth factor $\beta$ (TGF- $\beta$ ) family. Structurally related ligands, receptors, and Smad proteins are grouped and shown in the same boxes.

(Bragdon et al. 2011). Although BMP homodimers are produced and examined in vitro and in vivo, some heterodimers show enhanced activities (Israel et al. 1996; Guo and Wu 2012). BMP-2/7 and BMP-4/7 heterodimers have been implicated in mesoderm induction and differentiation of bone marrow cells, respectively (Suzuki et al. 1997; Yuan et al. 2011).

Crystal structures of BMP homodimers have revealed that the core structures of BMP dimers consist of a "cystine-knot" structure, and that the overall structure of BMPs has a "wrist and knuckle" or "two bananas" shape (Griffith et al. 1996; Brown et al. 2005; Schreuder et al. 2005). Studies of the crystal structures of BMPs have also identified possible binding epitopes of BMPs to specific receptors and antagonists (Kirsch et al. 2000; Groppe et al. 2002; Greenwald et al. 2003; Brown et al. 2005; Schreuder et al. 2005).

\section{Receptors of BMPs}

BMPs, like other TGF- $\beta$ family members, elicit their effects through two types of serine- - threonine kinase transmembrane receptors, type I and type II receptors. Unlike TGF- $\beta$ s, BMPs are capable of binding to type I receptors in the absence of type II receptors. However, their binding affinities increase dramatically when both type I and type II receptors are present (Rosenzweig et al. 1995).

There are three type II receptors for BMPsthe BMP type II receptor (BMPRII), the activin type II receptor (ActRII), and activin type IIB receptor (ActRIIB) in mammals. Although BMPRII is specific for BMPs, ActRII and ActRIIB are shared by BMPs, activins, and myostatin. The BMPRII receptor encodes a short form and a long form with a carboxy-terminal tail with 530 amino acids after its kinase domain 
T. Katagiri and T. Watabe

(Rosenzweig et al. 1995). The long form is expressed in most types of cells, whereas the short form is expressed only in certain types of cells. These type II receptors appear to bind most BMP ligands and control the binding preferences of BMPs to type I receptors (Fig. 1). Like other members of TGF- $\beta$ family, the serine-threonine kinases of type II receptors for BMPs are constitutively active, and phosphorylate the glycine-serine-rich (GS) domain of the type I receptors on ligand binding (Fig. 2).
Among the seven type I receptors (activin receptor-like kinases 1 through 7; ALK-1-7) for TGF- $\beta$ family proteins, ALK-3 (BMPRIA), ALK-6 (BMPRIB), ALK-2, and ALK-1 serve as type I receptors for most of BMPs. ALK-3 and ALK-6 are structurally very similar to each other, and are distantly related to ALK-1 and ALK-2 that are structurally highly similar to each other. ALK-2 and ALK-3 are widely expressed in various types of cells. In contrast, ALK-6 is expressed in a more restricted manner, and ALK-1 expression is limited to endothelial cells

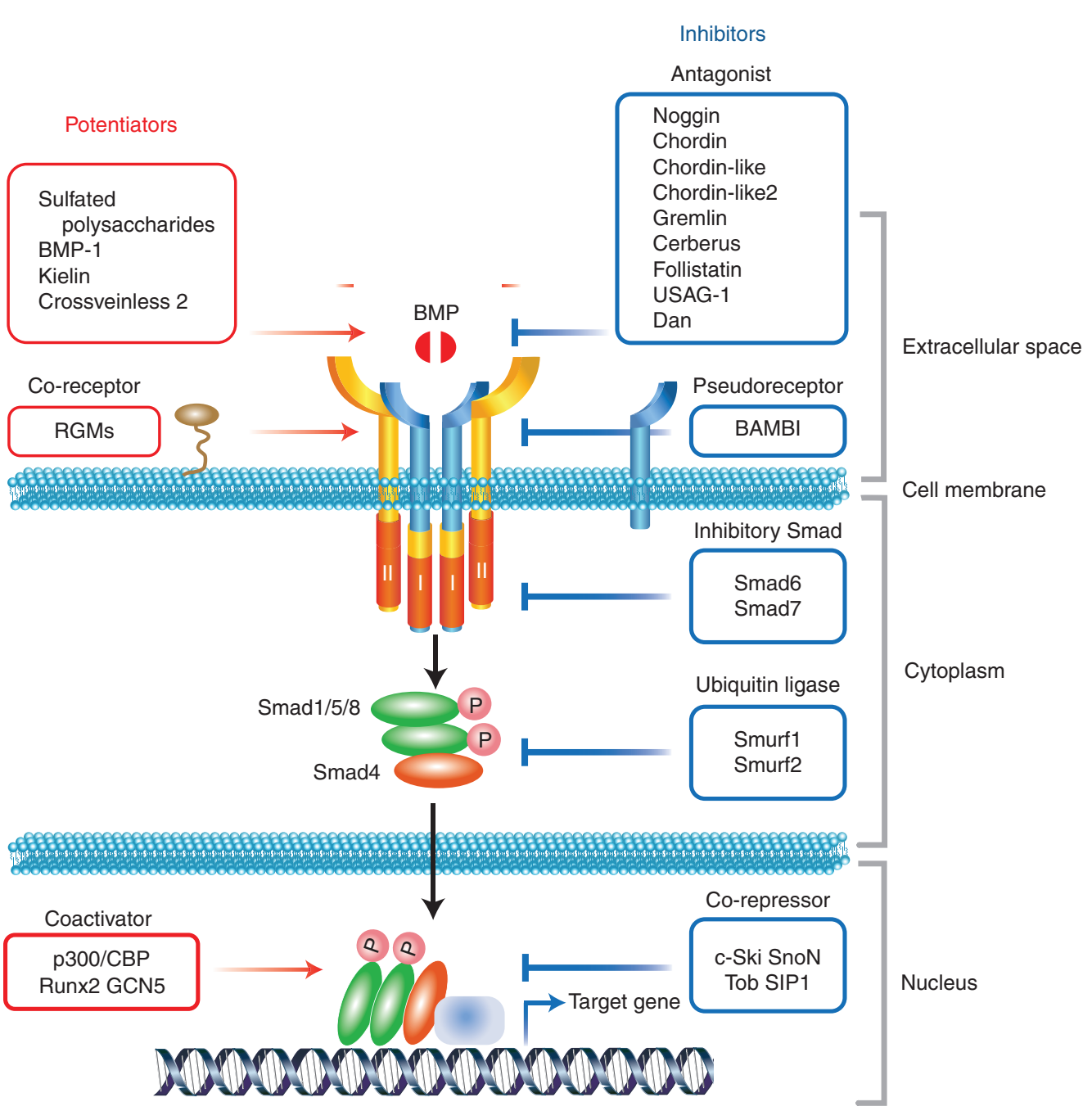

Figure 2. Potentiators and inhibitors of bone morphogenetic protein (BMP) signaling. Potentiators (left) and inhibitors (right) of BMP signaling are listed. These factors act on signaling extracellularly, at the membrane, in the cytoplasm, or in the nucleus. 
and certain other cells. The activated type I receptor kinases then phosphorylate downstream substrates in the cytoplasm, including Smad proteins (Miyazono et al. 2010).

The specificities of the binding of BMPs to type I receptors depend on the identities of the interacting type II receptors and cell types (Fig. 1) (Yu et al. 2005). BMP-2 and BMP-4 bind to ALK-3 and -6 (ten Dijke et al. 1994), whereas BMP- 6 and BMP-7 bind weakly to ALK-6 and strongly to ALK-2 (Ebisawa et al. 1999). GDF-5 preferentially binds to ALK-6 (Nishitoh et al. 1996). BMP-9 and BMP-10 bind to ALK-1 and ALK-2 (Brown et al. 2005; David et al. 2007). Some BMP type I receptors are shared by certain other members of the TGF- $\beta$ family. TGF- $\beta$ binds to ALK-5 (T $\beta R I$ ) as well as ALK-1 in cultured endothelial cells (Goumans et al. 2003).

In contrast to other BMPs, GDF-9 and BMP-3 have been reported to activate TGF- $\beta$ and activin type I receptors, that is, ALK-5 and ALK-4, respectively, leading to activation of Smad2 and Smad3 (Fig. 1) (Daluiski et al. 2001; Mazerbourg et al. 2004). Thus, GDF-9 and BMP-3 appear to activate signals similar to TGF- $\beta$ /activins, but distinct from those induced by other BMPs. BMP-3 has been shown to bind to ActRIIB and suppress BMP-2 and BMP-4 activity (Kokabu et al. 2012).

\section{Intracellular Signaling from Receptors}

Eight Smad proteins (Smad1 through Smad8) have been identified in mammals ( $\operatorname{Smad} 8$ is also known as Smad9). Activated BMP type I receptors phosphorylate receptor-regulated Smads (R-Smads), that is, Smad1, Smad5, and Smad8 (BMP-specific R-Smads) at their carboxy-terminal S-S-X-S motifs. The phosphorylated and activated R-Smad proteins form complexes with Smad4 (common partner Smad: coSmad), and move into the nucleus. Smad complexes containing two R-Smads and one Smad4 associate with various transcriptional coactivators (p300, CBP, Runx2, and/or GCN5) or co-repressors (c-Ski, SnoN, Tob, or SIP1), and bind to regulatory elements of target genes to regulate their transcription (Fig. 2).
During osteoblast differentiation, BMP-6 induces phosphorylation and nuclear accumulation of Smad1 and Smad5, but not of Smad8 (Ebisawa et al. 1999). Although Smad8 has been shown to be phosphorylated by BMP receptors, and transduce their signals (Kawai et al. 2000), a recent report showed that Smad8 forms complexes with Smad1 and bind to DNA, but suppresses the transcription of a reporter gene of BMP signaling as a dominant negative Smad (Tsukamoto et al. 2014). These findings suggest that Smad8 functions as a transducer and/or a new type of transcriptional regulator of BMP signaling.

BMPs also activate Smad-independent signaling pathways such as mitogen-activated protein kinases (MAPKs), c-Jun amino-terminal kinase (JNK), phosphoinositol-3 kinase (PI3K), Akt, and small GTPases (Derynck and Zhang 2003). These non-Smad pathways cooperate with Smad pathways to regulate various cellular responses.

\section{Target Genes for BMPs}

Progress in the genome-wide mapping of binding sites of Smad proteins using chromatin immunoprecipitation (ChIP) approaches, with promoter array analysis (ChIP-chip) and ChIP followed by sequencing (ChIP-seq), has revealed that Smad proteins co-occupy target sites with cell-type-specific master transcription factors (Morikawa et al. 2013). These findings suggest that BMP signals differentially regulate the expression of groups of target genes depending on the cellular contexts to elicit cell-type-specific functions. During osteoblast differentiation of early mesenchymal cells (e.g., C2C12 cells), numerous genes that regulate transcription and signal transduction were identified as immediate early genes (regulated within $2 \mathrm{~h}$ after BMP stimulation), including the inhibitor of differentiation or inhibitor of DNA-binding (Id) proteins Id1, Id2, and Id3, Smad6, Smad7, OASIS, Prx2, TIEG, and Snail (de Jong et al. 2004). In contrast, the intermediate (regulated up to $6 \mathrm{~h}$ after BMP-2 stimulation) and late (regulated up to $24 \mathrm{~h}$ after BMP stimulation) response genes are related to processes of osteoblastic dif- 
ferentiation, including the genes for transcription factors Hey1 and Tcf7, which mediate Notch and Wnt signaling, respectively. During angiogenesis, BMP-4 induces the expression of Id1, which is a common target of BMP signals, and the expression of angiogenesis-related genes including vascular endothelial growth factor receptor 2 (VEGFR2) and Tie2, which are receptors for VEGF and angiopoietins, respectively, and stimulates the proliferation of endothelial cells (Suzuki et al. 2008).

In the promoter region of the $I d 1$ gene, a GC-rich region located $\sim 1 \mathrm{~kb}$ upstream of the transcription start site was identified as the BMP-responsive element, and was found to show $100 \%$ identity between human and mouse genes (Katagiri et al. 2002; Korchynskyi and ten Dijke 2002; Lopez-Rovira et al. 2002). Smad1 and Smad4 bind to this element and synergistically activate $I d 1$ transcription. These results together with the findings that BMPs commonly induce Id1 expression in various types of cells suggest that Id1 is one of the direct targets for BMP signaling via Smad pathways in initiation of downstream events. Id1 through Id4 have similar, although not identical, biological activities. Id proteins interact with the basic helix-loop-helix (bHLH) transcription factors through their HLH domains. Because Id proteins do not bind DNA, they antagonize the transcription induced by bHLH transcription factors. Transcription factors of the bHLH family include MyoD and myogenin, which direct myogenesis, and NeuroD, Mash1, and neurogenin, which regulate neurogenesis. These findings suggest that BMP signals regulate the differentiation of various lineages of cells by inducing the expression of Id proteins. This notion has been confirmed by the finding that BMP induction of Id 1 suppresses differentiation of embryonic stem (ES) cells and sustains their self-renewal (Ying et al. 2003).

Smad6 is another important BMP early response gene (Takase et al. 1998). The proximal BMP-responsive element in the Smad6 promoter, which is important for activation by BMPs, contains a 28-bp GC-rich sequence, including four overlapping copies of the GCCGnCGC-like motif that is recognized by
Smad1 and Smad5 (Ishida et al. 2000). Because Smad6 is an inhibitory Smad (I-Smad), BMP signaling interferes with its own signaling by establishing a negative feedback loop mediated by Smad6, a direct target of BMP signaling, which will be further discussed below. Similar to Smad6, the expression of Smad8 is increased in response to BMP signaling, but not TGF- $\beta$ signaling, within $1 \mathrm{~h}$ (Tsukamoto et al. 2014).

\section{Regulators of BMP Signaling}

BMP signaling is regulated at multiple levels from the extracellular space to the nucleus (Fig. 2). In extracellular compartments, BMP signaling is limited by BMP antagonists, which function through direct binding to BMP, thus preventing their binding to specific receptors (Brazil et al. 2015). Various extracellular BMP antagonists, such as noggin, chordin, chordinlike 1, chordin-like 2, Gremlin, Cerberus, follistatin, ectodin/uterine sensitization-associated gene-1 (USAG-1), and DAN family members, have been identified in various animal species. Expression of some antagonists such as noggin and Gremlin is up-regulated by BMPs, suggesting that the antagonists establish a negative feedback loop (Kameda et al. 1999; Pereira et al. 2000).

BMP signaling is also negatively regulated at the cell membrane by BAMBI (BMP and activin membrane-bound inhibitor), a pseudoreceptor for the TGF- $\beta$ family. BAMBI lacks the intracellular domain of the serine-threonine kinase receptors, and inhibits ligand-induced signaling by preventing the formation of signaling receptor complexes (Onichtchouk et al. 1999). The expression of BAMBI is induced by BMP and TGF- $\beta$, which is another example of negative feedback of TGF- $\beta$ family signals (Onichtchouk et al. 1999). Intracellularly, BMP signaling is negatively regulated by I-Smads (Smad6 and Smad7), the E3 ubiquitin ligases Smurf1 and Smurf2, and transcriptional co-repressors, such as c-Ski, SnoN, and Tob.

In addition to antagonists, some extracellular potentiators of BMPs have been identified. BMP-1 is a metalloproteinase that cleaves pro-collagens (Kessler et al. 1996). Tolloid and 
Xolloid are BMP-1 homologs in Drosophila and Xenopus, respectively. Because they release active BMPs from inactive BMP-chordin complexes by cleavage of chordin, BMP-1 may also act as an activator of BMPs (Marques et al. 1997; Piccolo et al. 1997). Because mature BMPs are identified as heparin-binding forms, sulfated polysaccharides, such as heparin, heparan sulfate, and dextran sulfate, have been reported to potentiate BMP-2-, BMP-4-, and BMP-7-induced osteoblast differentiation (Ruppert et al. 1996; Irie et al. 2003; Takada et al. 2003). Kielin/ chordin-like protein (KCP) was identified from an embryonic kidney cDNA library as a protein, which has 18 cysteine-rich repeats and a von Willebrand factor type D domain (Lin et al. 2005). Although cysteine-rich repeats are frequently found in BMP antagonists, KCP binds BMPs and enhances BMP signaling in a paracrine manner. Crossveinless-2, also known as BMPER, is closely related to chordin and has been shown to function as both a potentiator and antagonist of BMP signals (Moser et al. 2003). When Crossveinless-2/BMPER is depleted in endothelial cells, sprouting phenotypes are diminished with decreased BMP signals (Heinke et al. 2008).

BMP signals are also positively regulated by their coreceptor, glycosylphosphatidylinositol (GPI)-anchored membrane proteins of the repulsive guidance molecule (RGM) family, including RGMa, RGMb (also known as DRAGON), and RGMc (also known as hemojuvelin or HFE2) (Nili et al. 2010). RGMs form complexes with BMP type I receptors, bind selectively to BMP-2 and BMP-4, but not to BMP-7 or TGF- $\beta 1$, and enhance BMP signaling (Babitt et al. 2005, 2006; Samad et al. 2005). In the nucleus, transcriptional coactivators, such as p300 and CBP, are required for the transcriptional activity of phosphorylated BMP-specific R-Smads through complex formation. Several transcription factors, including Runx2, interact with Smad 1 and 5 and participate in the transcription of some BMP-specific target genes. These potentiators and inhibitors of BMP signals are expressed in a cell-type-specific manner, and play important roles in various biological activities of BMPs.

\section{Expression of BMPs}

Although most BMPs are expressed in a variety of tissues during embryogenesis, the expression of some members becomes restricted to specific tissues after birth. For example, BMP-3, $-4,-5$, and -6 are highly expressed in lung, whereas BMP-7 is abundantly expressed in kidney in adult mice (Özkaynak et al. 1992). Osteoblasts and osteocytes, which are terminally differentiated osteoblasts embedded in secreted bone matrix, are an important source of BMPs in bone matrix, and expression of some BMP mRNAs is induced during bone formation. BMP-3 is abundantly expressed by osteoblasts and osteocytes in mice (Kokabu et al. 2012). BMP-4 expression is transiently induced in callus-forming cells in the early phase of fracture healing (Nakase et al. 1994). The expression of BMP-4 is enhanced by BMP signaling itself and is higher in lymphoblastoid cells established from patients with fibrodysplasia ossificans progressiva (FOP), which is caused by gain-of-function mutation of a BMP receptor, than that in control cells (Shafritz et al. 1996). BMP-6 is highly expressed in hypertrophic chondrocytes, which are cells with cartilage and bone cell characteristics during endochondral ossification (Lyons et al. 1989). BMP-9 is produced by hepatocytes, and circulates in plasma both as an unprocessed inactive form $(40 \%)$ and as a mature and fully active form (60\%) (Bidart et al. 2012). The level of circulating BMP-9 in plasma of healthy adult human is $6.2 \pm 0.6 \mathrm{ng} / \mathrm{ml}$ with a range variation between 2 and 12, and is enough to induce a constitutive Smad1/5/8 phosphorylation in endothelial cells (David et al. 2008). These results suggest that BMPs are capable of acting not only as local but also as systemic factors.

\section{BIOLOGICAL ACTIVITIES OF BMPs IN SKELETAL TISSUES}

BMPs play critical roles in the development and maintenance of various tissues in vertebrates and invertebrates by regulating cell proliferation, differentiation and death. Considering the discovery of BMPs in the context of skeletal 
T. Katagiri and T. Watabe

repair, we first review the major biological activities in skeletal tissues.

\section{Skeletal Development}

It is not clear whether all BMPs have bone-inducing activity in vivo. BMP-2, BMP-4, BMP-6, and BMP-7 have been shown to induce formation of bone and cartilage tissues in vivo, whereas GDF-5 induces cartilage and tendon-like tissues in vivo (Fig. 3) (Wozney et al. 1988; Celeste et al. 1990; Sampath et al. 1992; Wolfman et al. 1997). The osteogenic activities of 14 BMPs were evaluated using an adenoviral gene transfer technique in vitro (Cheng et al. 2003). Among them, BMP-2, BMP-6, and BMP-9 were most potent in inducing alkaline phosphatase activity and osteocalcin expression in murine pluripotential $\mathrm{C} 3 \mathrm{H} 10 \mathrm{~T} 1 / 2$ cells, and were found to play important roles in inducing osteoblast differentiation of mesenchymal progenitor cells. In contrast, most BMPs other than BMP-3 and BMP-12 were able to induce alkaline phosphatase activity in human osteosarcoma TE- 85 cells, and to induce osteogenesis in mature osteoblasts.

Analyses of mice and humans with skeletal abnormalities have identified loss-of-function or gain-of-function mutations in BMP signaling molecules, confirming that BMPs are important regulators for normal skeletal development. The mutant mouse "short ear" has de-
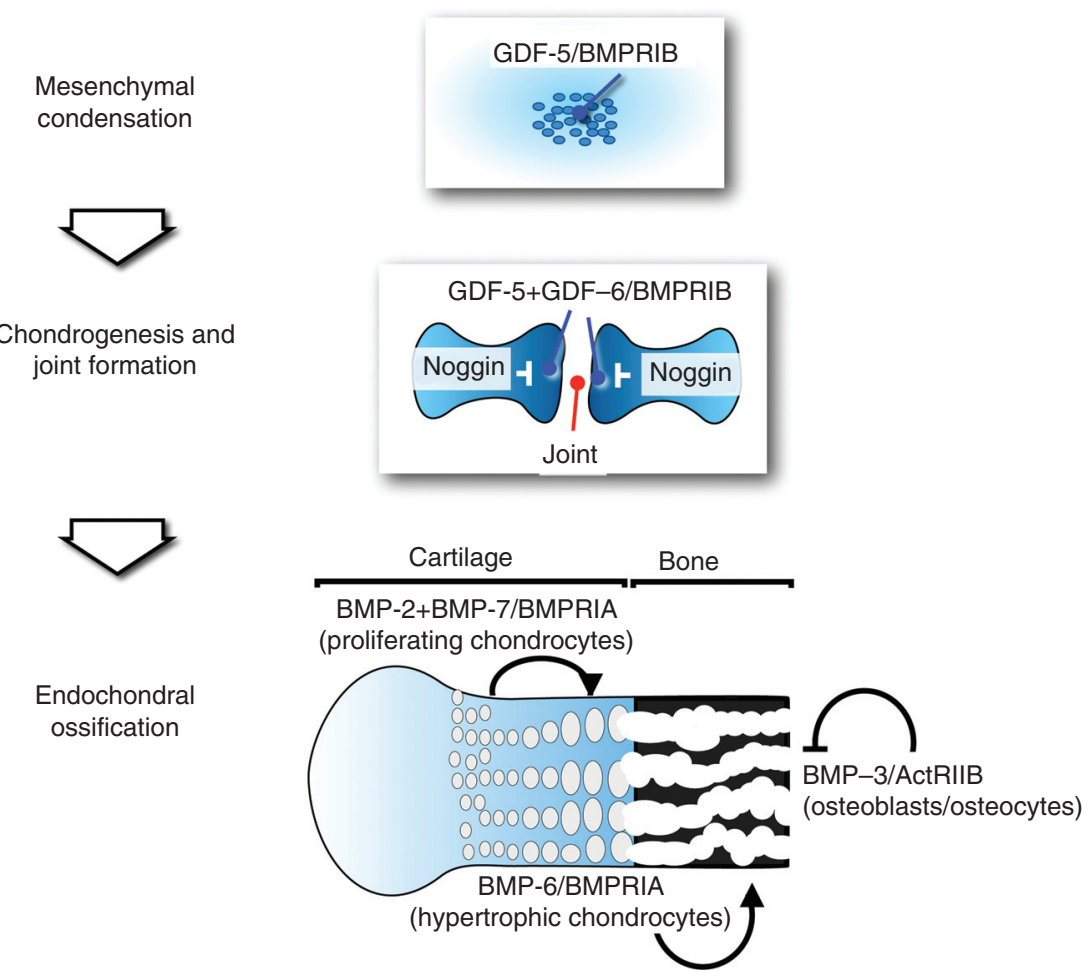

Figure 3. Roles of bone morphogenetic protein (BMP) signaling in skeletal development. Most skeletal elements are formed by endochondral ossification, in which undifferentiated mesenchymal cells condense in response to a GDF-5 signal (top). The cells differentiate into chondrocytes and form cartilaginous tissues. GDF-5 and GDF-6 promote cartilage development through BMPRIB, but noggin suppresses this process as a BMP antagonist to lead a joint formation (middle). The proliferating chondrocytes further differentiate into hypertrophic chondrocytes, and then the terminally differentiated chondrocytes are replaced by bone tissue (bottom). Chondrocyte differentiation is stimulated by BMP-2, BMP- 6 , and BMP-7 secreted by the chondrocytes themselves, and bone formation is suppressed by BMP-3 secreted by osteocytes. 
fects in growth and patterning of skeletal structures and in repair of bone fractures in adults. In these mice, the Bmp5 gene is deleted or rearranged in several independent mutations at the short ear locus (Kingsley et al. 1992). Bmp6 $6^{-/-}$ mice are indistinguishable from wild-type mice, but they have mild cartilage phenotypes (Solloway et al. 1998). Bmp $7^{-1-}$ mice have skeletal patterning defects restricted to the rib cage, skull, and hindlimbs (Dudley et al. 1995; Luo et al. 1995). Doubly heterozygous $B m p 4^{+/-}$; $B m p 7^{+/-}$mice develop minor defects in the rib cage and the distal parts of limbs (Katagiri et al. 1998). Mutations in the Gdf5 gene are responsible for skeletal alterations in brachypodism (bp) mice, which are characterized by skeletal abnormalities restricted to the limbs and limb joints (Storm et al. 1994). Inactivation of the Gdf6 gene causes defects in joint, ligament, and cartilage formation at sites distinct from those seen in Gdf5 mutants (Settle et al. 2003). Mice lacking both the Gdf5 and Gdf6 genes show additional defects, including severe reduction or loss of some skeletal elements of the limbs, additional fusions between skeletal structures, scoliosis, and alterations of cartilage in the intervertebral joints of the spinal column (Settle et al. 2003). Homozygous Gdf11 mutant mice show anteriorly directed homeotic transformations throughout the axial skeleton and posterior displacement of the hindlimbs (McPherron et al. 1999). Interestingly, $B m p 3^{-/-}$mice have twice as much trabecular bone after birth as wild-type littermates (Daluiski et al. 2001). BMP-3 suppresses osteoblastic differentiation of bone marrow stromal cells in vitro by binding to ActRIIB without activating BMP intracellular signaling (Kokabu et al. 2012).

A noggin/GDF-5/ALK-6 axis has been identified as a critical signaling pathway for chondrogenesis during limb development (Fig. 3). GDF-5 is abundantly present in mesenchymal condensations before chondrocyte differentiation in embryonic development (Tsumaki et al. 1999). In contrast, noggin, its antagonist, is expressed in joint-forming spaces, which are formed by termination of the chondrogenesis in the cartilage (Brunet et al. 1998). The biological activities of the TGF- $\beta$ family members on chondrogenesis have been examined in vitro in high-density micromass cultures of mesenchymal cells prepared from limb bud (Nakayama et al. 2003; Seemann et al. 2005). TGF- $\beta$-induced chondrogenesis was inhibited by noggin, suggesting that BMP signaling is involved in this process (Nakayama et al. 2003). Multiple synostoses syndrome, which is characterized by fusion of multiple joints, is caused by an overactivation of BMP/GDF activity as a result of loss-of-function mutations in noggin protein or gain-of-function mutations in GDF-5 (Gong et al. 1999; Dawson et al. 2006). In contrast, a suppression of BMP/GDF activity caused by loss-of-function mutations in GDF-5 or its receptor ALK-6 has been shown to be linked to brachydactylies (Polinkovsky et al. 1997; Thomas et al. 1997; Lehmann et al. 2006).

\section{Osteoblast and Chondrocyte Differentiation}

BMPs regulate proliferation and/or differentiation of osteoblasts and chondrocytes, which develop from a common population of undifferentiated mesenchymal stem cells that have pluripotency to differentiate into multiple types of cells such as adipocytes, tenocytes, and myocytes as well. Generally, osteogenic BMPs induce heterotopic bone in soft tissue via endochondral ossification, in which the undifferentiated mesenchymal cells differentiate into chondrocytes secreting cartilage-specific extracellular matrices, such as type II collagen and various proteoglycans, within a week after implantation (Wang et al. 1990). Osteoblasts appear in the perichondrium close to mature hypertrophic chondrocytes in endochondral ossification. In contrast, in intramembranous ossification, the mesenchymal cells directly differentiate into osteoblasts secreting bone-specific extracellular matrices, such as type I collagen, osteopontin, and osteocalcin. Implantation of BMP-2 induces cartilage by day 7 and bone by day 14 , with bone formation dependent on the amount of BMP-2 (Wang et al. 1990). Bone formation could be observed at 5 days using higher doses of BMP-2. Although BMP-2 induces differentiation of chondrocytes and osteoblasts 
in vitro, BMP-2 failed to convert the differentiation pathway from chondrocytes to osteoblasts and vice versa (Komaki et al. 1996). The fate of progenitor cells to differentiate into chondrocytes or osteoblasts in response to BMP signaling may be modulated by their microenvironment.

Expression of constitutively active forms of BMP type I receptors, such as BMPRIA, BMPRIB, ALK-2, and ALK-1, induces osteoblastic differentiation in vitro without adding exogenous ligands (Akiyama et al. 1997; Chen et al. 1998; Fujii et al. 1999; Zhang et al. 2003). FOP is the first identified disorder caused by natural gain-of-function mutations of the BMP receptor ALK-2. FOP is characterized by progressive heterotopic bone formation in soft tissues, such as skeletal muscle, tendon, and ligament, similar to the effects of implantation of BMPs (Katagiri 2010, 2012; Kaplan 2013). Increased expression of the mutant ALK-2 in vitro activates intracellular signaling without adding ligands, and enhances the chondrogenesis in micromass cultures and the osteoblastic differentiation in C2C12 myoblasts (Fukuda et al. 2008, 2009; Shen et al. 2009; Fujimoto et al. 2014, 2015). Twelve types of mutant ALK-2 are found in patients with FOP, and they mildly activate BMP signaling without adding ligands. However, their activities are further enhanced by the presence of type II BMP receptors, such as BMPRII and ActRIIB, but not ActRII (Fujimoto et al. 2015). Activin A induces phosphorylation of Smad 1/ 5 through the mutant ALK-2 responsible for FOP, but not wild-type ALK-2 (Hastell et al. 2015). Moreover, a neutralizing antibody against activin $\mathrm{A}$ inhibits heterotopic bone formation in model mice of FOP (Hastell et al. 2015). It is of note that common activating mutations in ALK-2 found in FOP patients are related to the pathogenesis of diffuse intrinsic pontine gliomas (DIPGs), a rare type of glioma that occurs exclusively in children (Pacifici and Shore 2016).

Smad1 and Smad5 are critical effectors of BMP type I receptors, although other signaling pathways induced by BMP receptors, such as MAPK pathways, also affect the BMP-induced osteoblast differentiation. Substitution of two serine residues at the carboxy-terminal serine-valine-serine (SVS) motif in Smad1 to aspartic acid (DVD) activates the transcriptional activity without the need for phosphorylation by the receptors (Nojima et al. 2010), and expression of such mutant Smad1 induces osteoblast differentiation in $\mathrm{C} 2 \mathrm{C} 12$ cells and ventralization in Xenopus embryos (Nojima et al. 2010). Similar mutations activate both Smad5 and Smad8, but a Smad8 mutant showed lower activity than the corresponding Smad1 or Smad5 mutants (Tsukamoto et al. 2014). It is still unclear how Smad1 and/or Smad5 induce bone or cartilage formation. The transcription factor Osterix was shown to be expressed in $\mathrm{C} 2 \mathrm{C} 12$ cells in response to BMP-2, and is critically required for osteoblast differentiation in vivo, as apparent from the phenotype of Osterix ${ }^{-/-}$mice (Nakashima et al. 2002). Runx2, Dlx-2, Dlx-5, and SOX6 are also involved in the BMP-induced osteoblast or chondrocyte differentiation, suggesting that multiple transcription factors are involved in the Smad1-/5-induced bone and cartilage formation (Ducy et al. 1997; Miyama et al. 1999; $\mathrm{Xu}$ et al. 2001; Fernandez-Lloris et al. 2003; Maeda et al. 2004).

\section{BIOLOGICAL ACTIVITIES OF BMPs IN OTHER TISSUES}

\section{Skeletal Muscle}

Skeletal muscle is one of the target tissues of BMPs, and BMP signaling induces skeletal tissue development in skeletal muscle tissue during embryonic development and in some pathological conditions. Skeletal muscle tissue contains not only multinucleated muscle fibers but also several types of mononuclear cells, including satellite cells, endothelial cells, smooth muscle cells, and mesenchymal interstitial cells, which are potential progenitor cells of chondrocytes and osteoblasts induced by BMPs (Lounev et al. 2009; Medici et al. 2010; Wosczyna et al. 2012). Satellite cells and myoblasts were believed to be progenitor cells of the chondrocytes and osteoblasts, because osteogenic BMPs induce osteoblastic differentiation in $\mathrm{C} 2 \mathrm{C} 12$ 
myoblasts (Katagiri et al. 1994). However, celllineage-tracing experiments in vivo using celltype-specific fluorescent marker expression showed that MyoD- or Myf5-expressing myogenic cells do not incorporate well into BMPinduced cartilage or bone tissue (Lounev et al. 2009). Heterotopically induced chondrocytes and osteoblasts, but not normal chondrocytes or osteoblasts, are positive for the endothelial marker Tie-2 (Medici et al. 2010). Moreover, BMP treatment induces Tie-2-expressing endothelial cells to differentiate into osteoblasts, chondrocytes, and adipocytes via endothelialto-mesenchymal transition (EndMT) (Medici et al. 2010). Nonmyogenic interstitial cells in the skeletal muscle, which are positive for Tie-2, platelet-derived growth factor receptor $\alpha$ (PDGFR $\alpha)$ and Sca-1, were identified as progenitors of both chondrocytes and osteoblasts induced by BMP-2 in vivo (Wosczyna et al. 2012). In these experiments, the CD31- or VE-cadherin-expressing endothelial cells did not differentiate into osteoblasts or chondrocytes in the BMP-induced heterotopic skeletal tissues (Wosczyna et al. 2012). These findings suggest that several types of progenitor cells could differentiate into osteoblasts and chondrocytes in response to osteogenic BMP signaling in the skeletal muscle.

The skeletal muscle mass is physiologically controlled by the TGF- $\beta$ family signaling, including osteogenic and nonosteogenic members. Myostatin/GDF- 8 , a TGF- $\beta$ family member that is specifically expressed in skeletal muscle, is a negative regulator of skeletal muscle mass, and myostatin-deficient animals, from zebrafish to humans, show marked increase in the skeletal muscle mass rather than fiber numbers. Osteogenic BMP signaling (phosphorylated Smad1/5) was also detected in normal skeletal muscle (Sartori et al. 2013). Surprisingly, adenoviral expression of noggin inhibited the muscle hypertrophy in myostatin-deficient mice, suggesting that BMPs promote increased skeletal muscle mass formation in these mice (Sartori et al. 2013). Moreover, the expression of BMP-14/GDF-5 mRNA was increased in a mouse model of denervation-induced sarcopenia, and overexpression of a constitutively active
BMPRIA-induced muscle hypertrophy in vivo (Sartori et al. 2013; Winbanks et al. 2013).

BMPs are potent inhibitors of myogenesis. Expression of Id1, Id2, and Id 3 is induced by the transcriptional complexes consisting of phosphorylated Smad1/5 and Smad4, and they suppress the transcriptional activity of myogenic bHLH factors such as MyoD and Myf5 (Katagiri et al. 1994; Hollnagel et al. 1999; Kowanetz et al. 2004; Shin et al. 2013). Nuclear localization of Smad4 with E4F1 has been shown to be involved in the expression of Id1 and BMPinduced inhibition of myogenesis (Nojima et al. 2010). MUSA-1, a ubiquitin ligase, has been identified as a target of both BMP and myostatin signaling to control skeletal muscle mass (Sartori et al. 2013). BMP-induced Smad1/5-Smad4 signaling inhibits the expression of MUSA-1 by competing with the formation of Smad2/3-Smad4 complexes induced by myostatin (Sartori et al. 2013). These findings indicate that skeletal muscle mass is regulated in a balance between BMP/GDF and myostatin/activin intracellular signaling through Smad4.

\section{Adipogenesis and Fat Tissues}

BMP signaling plays important roles in adipogenesis, not only in maturation of pre-adipocytes, but also in commitment of undifferentiated progenitor cells. BMP-2, BMP-4, and BMP-7 stimulate adipogenesis of C3H10T1/2 cells that show a pluripotency to differentiate into myocytes, adipocytes, chondrocytes, and osteoblast-like cells (Wang et al. 1993; Asahina et al. 1996; Bächner et al. 1998). Similar stimulation of adipogenesis by BMP-2 was observed in a typical pre-adipocyte cell line, 3T3-L1. BMPRIA, but not BMPRIB, was shown to promote adipogenesis, suggesting that BMP ligands that bind BMPRIA with high affinity, such as BMP-2 and BMP-4, are involved in adipogenesis (Chen et al. 1998). Gremlin-1, a BMP antagonist, is secreted by pre-adipocytes and prevents maturation into mature adipocytes induced by BMPs (Gustafson et al. 2015).

Although BMPs are important for white adipose tissue formation, BMP signaling also reg- 
T. Katagiri and T. Watabe

ulates brown adipose tissue formation. Both types of adipose tissue are related but have distinct functions, resulting in energy storage and energy expenditure, respectively. Brown adipose tissue develops from Myf5-expressing cells following stimulation with BMP-7 (Tseng et al. 2008). BMP-7 induces commitment of mesenchymal progenitor cells to brown adipocyte lineage cells, and $B m p 7^{-/-}$mice show a reduction of brown fat (Tseng et al. 2008). BMP-7 activates PRDM16, a zinc finger transcription factor that promotes brown adipocyte differentiation, and both the p38 MAPK and Smad1/5 signaling pathways in brown, but not white adipose cells (Tseng et al. 2008). BMP-8b is also expressed in brown adipose tissue and increases thermogenesis not only locally but also systemically through central nerve systems (Whittle et al. 2012). Furthermore, a balance between
BMP and TGF- $\beta$ signaling regulates brown adipogenesis through a regulation by Bmal1, a circadian clock transcription factor (Nam et al. 2015). These finding indicate that multiple BMP ligands regulate both white and brown adipocyte differentiation in vivo.

\section{Tooth Development}

Epithelial and mesenchymal interactions control normal tooth development by regulating the differentiation of enamel-producing ameloblasts and dentin-producing odontoblasts from epithelium and mesenchyme, respectively (Fig. 4). These interactions are controlled by the expression and activities of BMPs, their receptors and antagonists. BMP signaling has been suggested to play an important role in the epithelial-mesenchymal interactions during tooth

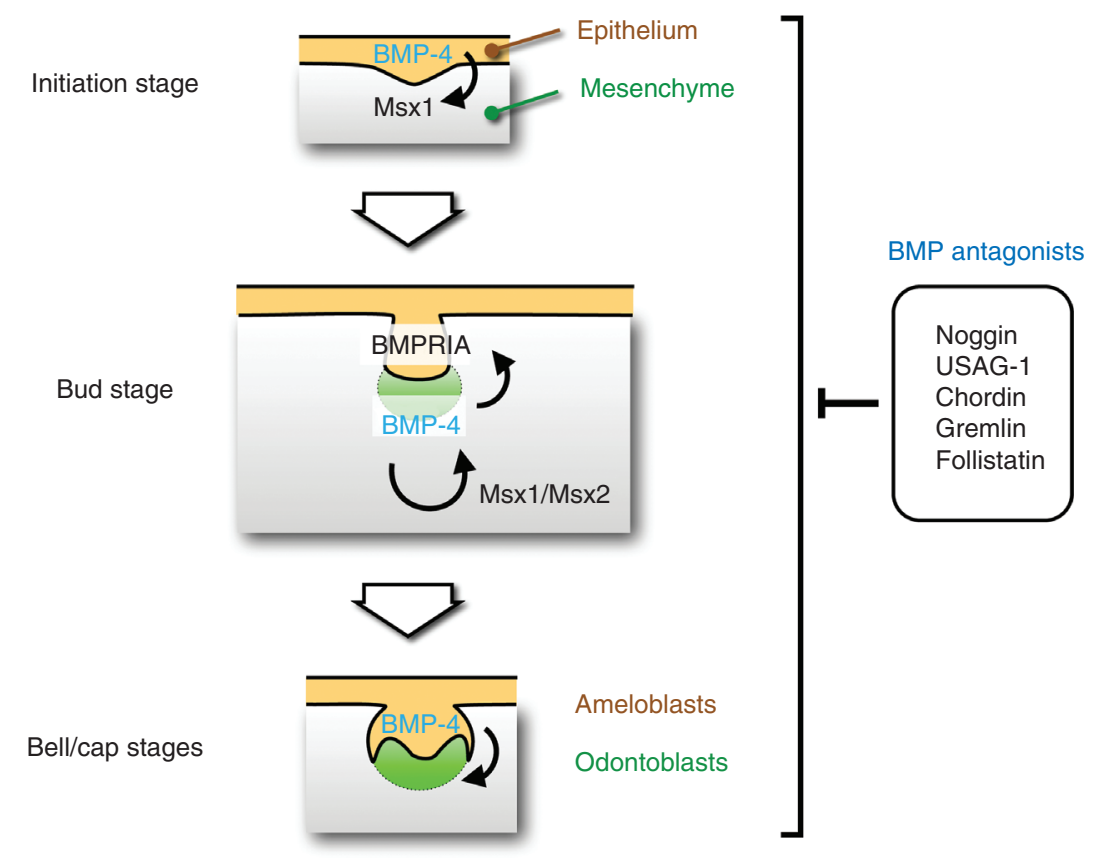

Figure 4. Bone morphogenetic proteins (BMPs) are secreted key regulators of an epithelial-mesenchymal interaction in tooth development. Teeth are formed by an epithelial-mesenchymal interaction during tooth development. At an initiation stage, BMP-4 from epithelial cells initiates tooth development through Msx1, a homeobox-containing transcription factor, in mesenchymal cells (top). BMP-2 and BMP-4 from mesenchymal cells act as a positive signal on BMPRIA in initiation of differentiation of epithelial cells at a bud stage (middle). At the bell and cap stages, BMP from epithelial cells regulates odontoblast differentiation in mesenchyme (bottom). BMP signaling is inhibited by BMP antagonists, including noggin, USAG-1, chordin, Gremlin, and follistatin. 
development. BMP-2 and BMP-4 as well as their type I receptor BMPRIA are highly expressed in rat molar development at cap stage (Ikeda et al. 1996). Additionally, beads soaked with BMP-2 or BMP-4 mimicked the interactive signaling between epithelial and mesenchymal cells in tooth development in an ex vivo culture system (Vainio et al. 1993). Depletion of BMPRIA in keratin 5-expressing epithelial cells using a CreLoxP system caused enamel defects and induced ectopic cementum-like structures (Yang et al. 2013). The ectopic cement-like phenotype was rescued by conditional depletion of $\beta$-catenin in epithelial cells, suggesting that Wnt signaling is involved in the phenotype (Yang et al. 2013). The expression of homeobox-containing transcription factors Msx1 and Msx2 was increased by BMP-4 signaling in dental mesenchymal cells (Vainio et al. 1993; Tucker et al. 1998a,b; Zhang et al. 2002). BMP-4 failed to induce its own expression in $\mathrm{Msxl}^{-/-}$mice-derived cells and BMP-4 rescued the phenotype of $M s \times 1^{-/-}$ tooth germs, suggesting that BMPs regulate dental epithelial-mesenchymal interactions through the expression of Msx 1 and Msx2 during early tooth development (Zhang et al. 2002).

BMP antagonists, such as noggin, follistatin, and USAG-1, also regulate tooth development by suppressing BMP signaling. Exogenous noggin in the developing mandible induces ectopic expression of Barx-1, a homeobox-containing transcription factor in the incisor mesenchyme, and a change in type of tooth from incisor to molar (Tucker et al. 1998b). Increased expression of noggin in dental epithelium causes a loss of odontogenesis in the epithelium (Wang et al. 2012). In contrast, in Noggin ${ }^{+/-}$mice, a single upper incisor is formed with normal molars and mandibular incisors (Hu et al. 2012). Chordin and Gremlin, which also prevent BMP binding to the receptors, are coexpressed with noggin in the developing lower incisor and molar. Ectopic expression of follistatin in dental epithelium in transgenic mice inhibited ameloblast differentiation in incisors, whereas ameloblasts differentiated ectopically on the lingual surface in Follistatin ${ }^{-/-}$mice (Wang et al. 2004). In cultured tooth explants, follistatin expression was induced by activin from the surrounding dental follicle (Wang et al. 2004). USAG-1 is abundantly expressed in teeth as a "negative" image of mouse enamel knots (Laurikkala et al. 2003; Kasai et al. 2005). USAG-1-deficient mice showed enlarged enamel knots, markedly altered cusp patterns, extra incisors and molars, and fused molars (Kasai et al. 2005; Yanagita et al. 2006). The supernumerary maxillary incisor formed as a result of the successive development of the rudimentary upper incisor (Murashima-Suginami et al. 2008). Inhibition of BMP signaling rescues supernumerary tooth formation in incisor explants (Murashima-Suginami et al. 2008). These findings indicate that both positive and negative type regulators of BMP signaling control normal tooth development (Fig. 4).

\section{Hair Follicle Development}

As described above in the section on tooth development, epithelial-mesenchymal interactions mediated by BMP signals play important roles in the development and regeneration of hair follicles. Hair follicles, which are appendages of skin epithelium, arise from the embryonic ectoderm and undergo cyclic regeneration during postnatal life.

During embryogenesis, skin epithelium arises from the single layer of ectoderm that surrounds the embryo body (Lee and Tumbar 2012). Starting around E14.5, the primary hair follicle, which gives rise to guard hair, develops, followed by the formation of secondary hair follicles, which make up the majority of hair follicles. Compartmentalization and differentiation of hair follicles continue up to $\sim 2.5$ weeks after birth. During the formation of hair follicles, epidermal keratinocytes are stimulated by instructive signals from the underlying dermal mesenchyme. Such instructive signals for hair follicle morphogenesis include Wnt, Hedgehog, fibroblast growth factor (FGF), and BMPs. During the initiation of hair follicle morphogenesis, suppression of BMP and FGF signaling in combination with activation of Wnt signaling is required for epidermal cells to differentiate to hair follicles. During the maturation of hair follicles, 
BMP signals are necessary for proper hair follicle differentiation. Deletion of Bmpr1a results in abnormal hair follicle formation with a lack of lineage-specific differentiation markers (Andl et al. 2004). After birth, the lower portion of the mature hair follicle is regressed by apoptosis, and enters into a quiescent stage, which is regulated by BMP signals. In summary, multiple signals including BMPs are involved in proper follicular development: lineage specification, maturation, and regression. It is of note that the different combinations of the same signaling pathways during specific time windows and in distinct cell populations play important roles in hair follicle morphogenesis.

Around 20 days after birth, hair follicles enter a quiescence stage, but are ready to reactivate on signals from the environment. In adult skin, hair follicles undergo cycles through bouts of active hair growth (anagen), destruction (catagen), and rest (telogen), also known as the "hair cycle." Hair follicle stem cells reside in the bulge and are the source of all hair follicle lineages (Tumbar et al. 2004). At telogen, on activation signals, some bulge hair follicle stem cells migrate out into hair germ where they lose stem-cell characteristics and become transitamplifying progenitor cells, followed by proliferation and differentiation, which give rise to differentiated hair follicle lineages and production of hair shaft (anagen). In catagen, cells in the lower hair follicle regress again by apoptosis (Lee and Tumbar 2012). The tightly controlled balance of multiple signaling pathways regulates the hair follicle cycling. Increased evidence suggests that hair follicle development and cycling are regulated by similar mechanisms that involve Wnt, Sonic hedgehog (Shh), and BMP signaling pathways (Lee and Tumbar 2012).

Multiple lines of evidence suggest that BMP signals play important roles in the hair cycle. Postnatal inhibition of BMP signals by ectopic expression of noggin impairs hair follicle formation (Kulessa et al. 2000). During the hair cycle, BMP-4, BMPRIA, and noggin show spatiotemporal changes in their expression patterns, and play important roles in the control of telogen-anagen transition of hair follicles (Botchkarev et al. 2001). During telogen,
BMP-4 is produced by both secondary germ keratinocytes and dermal papilla fibroblasts, and activates intracellular signals via BMPRIA, which is selectively expressed in the secondary germ, leading to prevention of the onset of anagen. Activation of hair growth phase is initiated on up-regulation of noggin in follicular epithelium and mesenchyme. BMP-4 plays inhibitory roles during hair follicle telogen-anagen transition (Botchkarev et al. 2001). Expression of BMP-4 and BMPRIA is down-regulated in the germinative compartment of early anagen hair follicles. Administration of BMP-4 blocks development of anagen in the secondary hair germ of the hair follicles. Of note, the anagen-inducing effect of noggin is partially mediated by activation of Shh signaling, which is essential for hair follicle morphogenesis and initiation of hair cycle. Shh is up-regulated in the hair follicle after noggin treatment, and is down-regulated by BMP-4 (Botchkarev et al. 2001). Furthermore, inhibition of BMP signals promotes Wnt signals in hair follicle stem cells, which induce hair follicle morphogenesis (Jamora et al. 2003). Indepth genomic profiling of hair follicle stem cells and transient-amplifying cells revealed that GATA3, Id1 and Id3, targets of phosphoSmad1/5, play important roles in the specification of hair follicle lineages (Genander et al. 2014). These findings suggest that epithelial and mesenchymal interactions mediated by BMP signals in combination with Wnt and Shh signals play important roles in the regulation of maintenance and lineage specification of hair follicle stem cells during hair cycle.

\section{Iron Homeostasis}

Several lines of evidence have suggested that BMP signaling is a regulator in iron homeostasis. Iron is stored mainly in erythrocytes and liver from the circulation. Hepcidin is a critical hormone synthesized in the liver and suppresses the transport of iron from intestinal cells to the circulation. Smad4 was identified as a positive regulator of hepcidin expression in the liver, because the expression of hepcidin mRNA was abrogated in Smad4-deficient hepatocytes (Wang et al. 2005). Juvenile hemochromatosis is 
an autosomal recessive disorder characterized by iron overload in various organs and linked to the HFE2 gene, which encodes HFE2/hemojuvelin/RGMc (Papanikolaou et al. 2004). BMP-2, BMP-4, and BMP-9 increase the expression of hepcidin mRNA in hepatocytes, and BMP-9 shows the most potent stimulation among them (Truksa et al. 2006). Because BMP-9 is highly expressed in liver and is present in circulating plasma (David et al. 2008), BMP9 has been suggested to act as an autocrine or paracrine regulator of iron homeostasis through HFE2/RGMc/hemojuvelin and Smad4 by regulating hepcidin expression in hepatocytes. The BMP type I receptors, BMPRIA and ALK-2, are expressed in hepatocytes and regulate iron homeostasis. Deletion of the genes encoding either BMPRIA or ALK-2 causes iron overload in mice (Steinbicker et al. 2011). BMPRIA is required for the hepcidin expression induced by interleukin-6 (Mayeur et al. 2014).

\section{Kidney Development}

A mammalian kidney contains approximately one million nephrons that consist of glomeruli, proximal tubules, loop of Henle, distal tubules, and collecting ducts. These structures develop through mutual interactions between the ureteric bud and the metanephric mesenchyme that contain nephron progenitors (Dressler 2006). BMP signals have been implicated in many steps of kidney development (Nishinakamura and Sakaguchi 2014). BMP-4 inhibits ureteric bud attraction. During midgestation, BMP-7 plays important roles in the maintenance of the nephron progenitors and, at the same time, sensitizes them to the ureteric bud-derived differentiation signal. Mice deficient for $B m p 7$ gene die shortly after birth because of poor kidney development (Dudley et al. 1995; Luo et al. 1995). In $B m p 7^{-/-}$ mice, increased apoptosis was observed in the embryonic renal mesenchyme (Luo et al. 1995). BMP-7 is abundantly expressed in the kidney, especially in distal tubule epithelial cells. BMP-7 reversed TGF- $\beta$-induced epithelial-mesenchymal transition (EMT) in renal tubular epithelial cells in vitro and in vivo (Zeisberg et al. 2003), and administration of large doses of BMP-7 reversed renal injury and improved renal function (Vukicevic et al. 1998; Hrusuka et al. 2000; Zeisberg et al. 2003). Furthermore, small peptide agonists of BMP signaling that function through the ALK-3 showed therapeutic benefits in repairing established renal fibrosis (Sugimoto et al. 2012).

Both potentiators and antagonists of BMPs are also expressed in the kidney. Deletion of Crossveinless-2, a potentiator of BMP signals, leads to kidney hypoplasia (Ikeya et al. 2010). After birth, when nephron progenitors disappear, Dullard, a phosphatase that inactivates $\mathrm{BMP}$ receptors, maintains BMP signals at an appropriate level. Lack of Dullard results in excessive BMP signals, leading to apoptosis of the postnatal nephrons. Mice deficient for KCP, a potentiator of BMP-7, were more susceptible to development of renal interstitial fibrosis and more sensitive to acute tubular injury, suggesting an important role for KCP in preventing renal fibrotic diseases (Lin et al. 2005). Mice lacking USAG-1, a BMP antagonist expressed abundantly in kidney, were resistant to renal injury (Yanagita et al. 2004, 2006). These findings indicate that signals regulated by BMP-7, as well as potentiators and antagonists of BMP signals play important roles in development and pathological conditions in the kidney.

\section{Pluripotent Stem Cells}

Pluripotent stem cells possess properties of selfrenewal and pluripotency (Hackett and Surani 2014). Mouse ES cells that are derived from inner cell mass of mouse blastocysts, possess "naïve" pluripotency. Proliferation and differentiation of mouse ES cells are regulated by multiple types of signaling cascades, including those mediated by BMPs (Itoh et al. 2014). Pluripotency of mouse ES cells is maintained in serum-containing medium supplemented with leukemia inhibitory factor (LIF). BMP-4 together with LIF is capable of substituting for serum and sustaining self-renewal of naïve mouse ES cells (Ying et al. 2003). Human ES cells are derived from human postimplantation embryos, and show more differentiated charac- 
teristics than naïve mouse ES cells. They are referred to be "primed" for differentiation, and have similar characteristics as mouse epiblast stem cells. Human ES cells and mouse epiblast stem cells are cultured in a LIF-independent condition, and can be maintained in the presence of FGF-2 and activin A, which maintain the primed pluripotent state. Full pluripotency, or a "ground state" of mouse ES cells has been shown to be maintained by a cocktail of two inhibitors of the MAPK kinase 1/2 (MEK1/2) and GSK3 pathways (Ying et al. 2008). However, the BMP-Smad pathway has been shown to be less active in the ground state of mouse ES cells (Boroviak et al. 2014). Furthermore, BMP-4 induces differentiation of primed pluripotent stem cells. These findings suggest that BMP signals play distinct roles in the maintenance and differentiation of pluripotent stem cells.

Mouse ES cell-like cells were generated from mouse embryonic fibroblasts by reprogramming using four transcription factors, Oct4, Sox2, Klf4, and c-Myc (Takahashi and Yamanaka 2006). These pluripotent stem cells are named "induced pluripotent stem (iPS) cells," share properties with mouse ES cells, such as expression of stem-cell markers, formation of teratomas, capacity to differentiate into all three germ layers, and generation of chimeric mice when iPS cells are injected into blastocytes. This reprogramming method was applied to human somatic cells to generate human iPS cells (Takahashi et al. 2007). In recent years, molecular mechanisms involved in iPS cell reprogramming have been studied, which has led to proposing a model that reprogramming consists of three phases: initiation, maturation, and stabilization (Samavarchi-Tehrani et al. 2010). The first step during the reprogramming is the morphological change from disperse fibroblasts to uniform and tightly packed ES cell-like cells. This morphological process is termed mesenchymal to epithelial transition, which is induced by BMP signals by inducing the expression of miR-205 and the miR-200 family (SamavarchiTehrani et al. 2010). BMPs can replace Klf4 in the reprogramming cocktail, allowing mouse embryonic fibroblasts to be reprogrammed using Oct4 alone (Chen et al. 2011). However, repro- gramming of human somatic cells is inhibited by constitutive activation of BMP signals ( $\mathrm{Ha}-$ masaki et al. 2012). These results also implicate the differential roles of BMP signals during the reprogramming of mouse and human iPS cells.

\section{Formation and Maintenance of Vascular Systems}

Tissue fluid homeostasis in vertebrates is maintained by the blood and lymphatic vascular systems. The crucial roles of BMP signals in the formation and maintenance of vascular systems have been identified in human hereditary vascular disorders, including hereditary hemorrhagic telangiectasia (HHT) and pulmonary arterial hypertension (PAH) (Cai et al. 2012). Furthermore, the role of BMP signaling in vascular development has been shown by studies in mouse models using a gene-targeting technique (Goumans and Mummery 2000).

BMPs have been reported to regulate the proliferation and migration of endothelial cells (David et al. 2009). Of the BMPs, BMP-2 and BMP-4 have been reported to regulate the proliferation of endothelial cells both positively (Valdimarsdottir et al. 2002; Suzuki et al. 2008) and negatively (Kiyono and Shibuya 2003). Roles of BMP-9 in the proliferation and migration of endothelial cells are also unclear because, at a high dose, BMP-9 inhibits endothelial cell proliferation (Scharpfenecker et al. 2007; David et al. 2008; Ricard et al. 2012), whereas a low dose of BMP-9 promotes proliferation of various types of endothelial cells in vitro, and angiogenesis in matrigel plug assays and human pancreatic cancer xenografts in vivo (Suzuki et al. 2010). It is likely that BMP-9 has disparate effects on endothelial cells depending on the cellular context and concentration of BMP-9 (Wiley and Jin 2011). BMP-6 and BMP-7 have been implicated in the onset of human diseases, such as cerebral cavernous malformation by inducing EndMT (Maddaluno et al. 2013).

Lymphatic vessels drain interstitial fluid that leaks from blood capillaries and return it to the blood vessels (Karpanen and Alitalo 2008). Dysfunction of the lymphatic system results in lymphedema, which is characterized by 
disabling swelling in the affected tissues. Lymphatic vessels also provide a major pathway for tumor metastasis in many types of cancer, and regional lymph node metastasis has been correlated with cancer progression. Inhibition of BMP-9 signals by administration of ALK-1-Fc, a soluble chimeric protein consisting of the extracellular part of ALK-1 fused to a Fc fragment, perturbs the postnatal lymphangiogenesis in the retina, tail, and ear skin, suggesting that BMP-9 signals are involved in lymphangiogenesis (Niessen et al. 2010). Multiple groups reported that BMP-9/ALK-1 signals inhibit the formation of lymphatic vessels in both physiological and pathological conditions by inhibiting proliferation of lymphatic endothelial cells (Levet et al. 2013; Yoshimatsu et al. 2013).

Tumor formation and progression requires newly formed blood vessels that supply cancer cells with oxygen and nutrients. BMP-9/ALK-1 signals have received a lot of attention as an anti-angiogenesis target because BMP-9-induced (tumor) angiogenesis can be pharmacologically inhibited by ALK-1-Fc, which serves as a ligand trap for endogenous BMP-9 and -10 (Cunha et al. 2010). Furthermore, ALK-1-Fc can decrease tumor growth and angiogenesis when combined with VEGFR inhibitor in vivo. These results suggest that targeting ALK1 may be a promising therapeutic strategy for cancer. Roles of BMP signals in tumor microenvironment are further discussed below.

\section{ROLES OF BMPS IN CANCER}

Multiple lines of evidence have suggested that BMP signals have divergent roles during the formation and progression of cancer by modulating both cancer cells and tumor microenvironments including tumor vessels (Ehata et al. 2013). It is of note that BMPs function as both suppressors and promoters of cancer in a context-dependent manner (Fig. 5).

\section{Genetic Implication of BMP Signals in Cancer}

Germline mutations in genes encoding ALK-3 (BMPR1A) and Smad4 (MADH4) have been found in subsets of patients with juvenile pol-

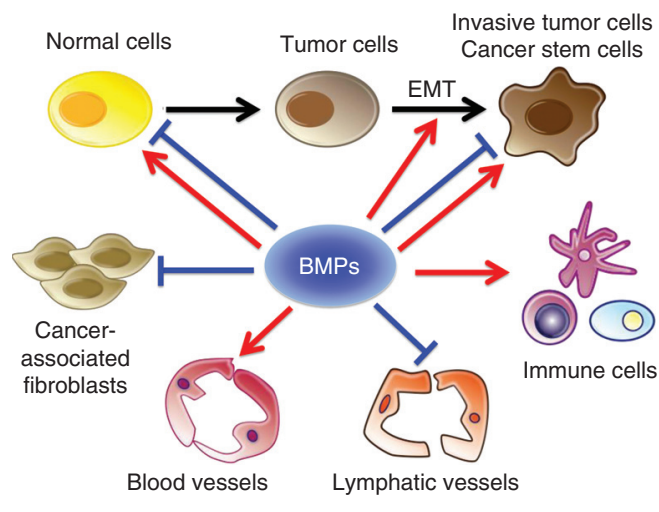

Figure 5. Roles of bone morphogenetic proteins (BMPs) in cancer. Pro- (red) and antitumorigenic (blue) effects of BMPs on various components of cancer microenvironments are shown. BMPs can either promote or suppress the proliferation and progression of cancer cells depending on the cellular contexts. EMT, Epithelial-mesenchymal transition.

yposis syndrome (Howe et al. 2001; Zhou et al. 2001), an autosomal dominant gastrointestinal hamartomatous-polypsis syndrome with risk for development of cancer. Furthermore, mutations in BMP signaling components, such as BMPRII and Smad4, in association with absence of phosphorylation of Smad1/5/8, have been observed in the majority of sporadic colorectal cancers (CRCs) (Kodach et al. 2008; Park et al. 2010). Consistent with these clinical observations, BMPs have been reported to inhibit the in vitro or in vivo proliferation of CRCs (Hardwick et al. 2004; Lee et al. 2008). In addition to CRC, in vitro and in vivo proliferation of prostate and diffuse-type gastric carcinoma were inhibited by BMP-7 and BMP-2/-4, respectively, through induction of $\mathrm{p} 21^{\mathrm{CIP} 1 / \mathrm{WAF} 1}$, leading to the hypophosphorylation of the retinoblastoma protein (RB) (Miyazaki et al. 2004; Shirai et al. 2011). These results suggest that BMPs act as tumor suppressors in multiple types of cancer (Ehata et al. 2013), which is also observed with TGF- $\beta$.

\section{Tumor Suppression by BMP Signals}

Tumor suppressing effects of BMPs are also elicited by their decrease in the size of populations 
of cancer stem cells. Cancer stem (or cancerinitiating) cells have stem-cell-like properties, such as self-renewal and multipotency. Because they show higher tumor-forming abilities and drug resistance than non-cancer stem cells, they have been implicated in growth and recurrence of many types of cancers. Although autocrine TGF- $\beta$ signals play important roles in maintaining the stem-cell-like properties and tumorigenic activity of glioma-initiating cells (GICs), BMP signals induce the differentiation of these cells (Piccirillo et al. 2006; Lee et al. 2008). BMPs also regulate the differentiation of other types of cancer stem cells, including colorectal and breast cancers (Lombardo et al. 2011; Buijs et al. 2012; Gao et al. 2012; Zhang et al. 2012). Taken together with their inhibitory effects on proliferation of various types of cancer cells, activation of BMP signals is expected to serve as a therapeutic strategy for cancer.

\section{Tumor Promotion by BMP Signals}

Although BMPs, similar to TGF- $\beta$ s, might also act initially as suppressors of many types of cancers, they also behave as tumor promoters during the progression of cancers. Intensity of BMP signaling appears to positively correlate with the degree of cancer malignancy and clinical stage in cancer patients (Helms et al. 2005; Alarmo et al. 2008; Choi et al. 2012; Voorneveld et al. 2013). BMP signals differentially modulate the initiation and progression of CRC depending on the Smad4 and p53 status (Voorneveld et al. 2015). Constitutive activation of Wnt signals plays important roles in the initiation, metastasis and chemosensitivity of CRC. BMP signaling inhibits Wnt signaling in CRC only when p53 and Smad4 are unaffected. In contrast, in Smad4 negative and/or p53 aberrant CRC, activation of Wnt signals (nuclear accumulation of $\beta$-catenin) was observed. These results suggest that use of BMPs in CRC therapy should be targeted to individual cancers based on the mutational status of p53 and Smad4. Furthermore, possible involvement of BMP signaling in cancer metastasis has recently been investigated (Alarmo and Kallioniemi 2010). Increasing evidence suggests that BMPs promote the motility and invasiveness of various types of cancer cells including breast cancer, lung cancer, prostate cancer, colon cancer, and malignant melanoma (Rothhammer et al. 2005; Yang et al. 2005; Bailey et al. 2007; Grijelmo et al. 2007; Katsuno et al. 2008). Of note, BMP-9 induces EMT of hepatocellular carcinoma cells to induce their invasiveness ( $\mathrm{Li}$ et al. 2013).

\section{Roles of BMP Signals in Tumor Stroma}

Tumor stroma plays important roles in cancer progression, and is composed of multiple components including blood vessels, fibroblasts, and inflammatory cells. As discussed, BMP-9/ALK1 signals promote tumor angiogenesis to alter the tumor microenvironment favorable for cancer growth. Pickup and colleagues investigated the requirement for BMPRII in stromal fibroblasts during the formation and metastasis of mammary carcinoma (Pickup et al. 2015). Genetic ablation of stromal BMPR2 expression using fibroblast-specific protein 1 (FSP1) promoter-driven Cre resulted in increased tumor metastasis in a transgenic mouse model of mammary carcinoma. Stromal loss of BMPRII results in increased inflammatory cell infiltration via increased secretion of inflammatory cytokines. In human breast cancer patients, the increased expression of chemokines in BMPRII-deleted cancers correlated with poor outcome, suggesting that BMP signals have tumor-suppressive roles in the stroma by regulating inflammation. BMP signals also create "pro-metastatic functions" in bone microenvironments where prostate cancer cells and osteoblasts interact with each other (Nishimori et al. 2012).

\section{BMP Signals as Therapeutic Targets}

These findings suggest that BMP signals are promising targets of cancer therapies. It was reported that the resistance of lung squamous cell carcinomas harboring mutations in the epidermal growth factor receptor (EGFR) gene to EGFR tyrosine kinase inhibitors (EGFR-TKIs) is partially a result of the activation of BMP signals (Wang et al. 2015). Treatment of these tumor cells with inhibitors specific to BMP re- 
ceptors effectively reversed the resistance to EGFR-TKI, suggesting that targeting BMP signals gives clinical benefit for squamous cell carcinomas with EGFR mutations. However, because BMPs have both tumor-promoting and suppressive functions, we need to carefully study the possible outcome when we use BMP ligands or BMP inhibitors, such as noggin and small molecule inhibitors to develop therapeutic strategies for cancers.

\section{CONCLUSIONS AND PERSPECTIVES}

BMP was originally identified as an ectopic bone-inducing activity in demineralized bone matrix in 1965. More than 20 BMPs have now been identified in various species, including mammals, Xenopus, Drosophila, and C. elegans. BMP receptors and the three classes of Smad proteins were identified by the late 1990s. Since the discovery of the molecules involved in BMP signaling cascades almost 20 years ago, we still have not fully understood how BMP family signals regulate the formation and maintenance of various organs in vivo. Combination of various ligands, signaling molecules, potentiators, and antagonists makes the BMP signaling cascades complex. BMP ligands have distinct profiles of expression and show distinct biological activities in vivo. Moreover, BMP antagonists and potentiators, which regulate BMP signals, also display distinct spatiotemporal profiles of expression. Thus, the biological activities of BMPs are tightly regulated by complex combination of various factors during various morphogenetic processes. Recent progress in experimental techniques, including ChIP-seq and next-generation high-throughput sequencing systems, may facilitate further understanding of in vivo functions of BMPs.

Studies of the physiological and pathological roles of BMP family members have revealed their clinical potentials not only in bone repair but also in other diseases such as vascular syndromes and cancer. Two BMP products, INFUSE (BMP-2) and OP-1 (BMP-7), have been approved by the U.S. Food and Drug Administration (FDA) for clinical application of fracture healing. However, clinical use of
BMPs has been hampered by several limiting factors such as their short half-lives and the possibility of undesired side effects. To date, usage of recombinant BMP proteins for fracture repair remains a highly expensive procedure with rather limited outcome. On the other hand, small molecule BMP agonists may overcome these limitations. Through a highthroughput screening, a stimulator of BMP signaling has been discovered, while its mode of action has not been elucidated (Balaramnavar et al. 2012). Like BMP agonists, small molecule inhibitors specific for BMP signaling have been developed (Yu et al. 2008a; Hong and Yu 2009; Boergermann et al. 2010; Mohedas et al. 2013; Sanvitale et al. 2013; Tsugawa et al. 2014). These inhibitors appear to be useful for the treatment of various diseases that are caused by activation of BMP signals, such as FOP (Yu et al. 2008b), DIPG (Pacifici and Shore 2016), and metastasis in certain types of cancer.

Thus, therapeutic use of activators and/or inhibitors of BMP signaling will provide potential avenues of opportunity for the treatment of various human diseases that are caused by lossor gain-of-functions of BMP signals.

\section{REFERENCES}

Akiyama S, Katagiri T, Namiki M, Yamaji N, Yamamoto N, Miyama K, Shibuya H, Ueno N, Wozney JM, Suda T. 1997. Constitutively active BMP type I receptors transduce BMP-2 signals without the ligand in $\mathrm{C} 2 \mathrm{C} 12$ myoblasts. Exp Cell Res 235: 362-369.

Alarmo EL, Kallioniemi A. 2010. Bone morphogenetic proteins in breast cancer: Dual role in tumourigenesis? Endocr Relat Cancer 17: 123-139.

Alarmo EL, Korhonen T, Kuukasjärvi T, Huhtala H, Holli K, Kallioniemi A. 2008. Bone morphogenetic protein 7 expression associates with bone metastasis in breast carcinomas. Ann Oncol 19: 308-314.

Andl T, Ahn K, Kairo A, Chu EY, Wine-Lee L, Reddy ST, Croft NJ, Cebra-Thomas JA, Metzger D, Chambon P, et al. 2004. Epithelial Bmprla regulates differentiation and proliferation in postnatal hair follicles and is essential for tooth development. Development 131: 22572268.

Asahina I, Sampath TK, Haushka PV. 1996. Human osteogenic protein-1 induces chondrogenic, osteoblastic, and/ or adipogenic differentiation of clonal murine target cells. Exp Cell Res 222: 38-47.

Babitt JL, Zhang Y, Samad TA, Xia Y, Tang J, Campagna JA, Schneyer AL, Woolf CJ, Lin HY. 2005. Repulsive guidance molecule (RGMa), a DRAGON homologue, is a bone 
morphogenetic protein co-receptor. J Biol Chem 280: 29820-29827.

Babitt JL, Huang FW, Wrighting DM, Xia Y, Sidis Y, Samad TA, Campagna JA, Chung RT, Schneyer AL, Woolf CJ, et al. 2006. Bone morphogenetic protein signaling by hemojuvelin regulates hepcidin expression. Nat Genet 38: $531-539$.

Bächner D, Ahrens M, Schröder D, Hoffmann A, Lauber J, Betat N, Steinert P, Flohé L, Gross G. 1998. Bmp-2 downstream targets in mesenchymal development identified by subtractive cloning from recombinant mesenchymal progenitors (C3H10T1/2). Dev Dyn 213: 398-411.

Bailey JM, Singh PK, Hollingsworth MA. 2007. Cancer metastasis facilitated by developmental pathways: Sonic hedgehog, Notch, and bone morphogenic proteins. J Cell Biochem 102: 829-839.

Balaramnavar VM, Khan IA, Siddiqui JA, Khan MP, Chakravarti B, Sharan K, Swarnkar G, Rastogi N, Siddiqui HH, Mishra DP, et al. 2012. Identification of novel 2-((1-(benzyl(2-hydroxy-2-phenylethyl)amino)-1-oxo-3-phenylpropan-2-yl)carbamoyl) benzoic acid analogues as BMP-2 stimulators. J Med Chem 55: 8248-8259.

Bidart M, Ricard N, Levet S, Samson M, Mallet C, David L, Subileau M, Tillet E, Feige JJ, Bailly S. 2012. BMP9 is produced by hepatocytes and circulates mainly in an active mature form complexed to its prodomain. Cell Mol Life Sci 69: 313-324.

Boergermann JH, Kopf J, Yu PB, Knaus P. 2010. Dorsomorphin and LDN-193189 inhibit BMP-mediated Smad, p38 and Akt signaling in $\mathrm{C} 2 \mathrm{C} 12$ cells. Int J Biochem Cell Biol 42: 1802-1807.

Boroviak T, Loos R, Bertone P, Smith A, Nichols J. 2014. The ability of inner-cell-mass cells to self-renew as embryonic stem cells is acquired following epiblast specification. Nat Cell Biol 16: 516-528.

Botchkarev VA, Botchkareva NV, Nakamura M, Huber O, Funa K, Lauster R, Paus R, Gilchrest BA. 2001. Noggin is required for induction of the hair follicle growth phase in postnatal skin. FASEB J 15: 2205-2214.

Bragdon B, Moseychuk O, Saldanha S, King D, Julian J, Nohe A. 2011. Bone morphogenetic proteins: A critical review. Cell Signal 23: 609-620.

Brazil DP, Church RH, Surae S, Godson C, Martin F. 2015. BMP signalling: Agony and antagony in the family. Trends Cell Biol 25: 249-264.

Brown MA, Zhao Q, Baker KA, Naik C, Chen C, Pukac L, Singh M, Tsareva T, Parice Y, Mahoney A, et al. 2005. Crystal structure of BMP-9 and functional interactions with pro-region and receptors. J Biol Chem 280: 2511125118.

Brunet LJ, McMahon JA, McMahon AP, Harland RM. 1998. Noggin, cartilage morphogenesis, and joint formation in the mammalian skeleton. Science 280: 1455-1457.

Buijs JT, van der Horst G, van den Hoogen C, Cheung H, de Rooij B, Kroon J, Petersen M, van Overveld PG, Pelger RC, van der Pluijm G. 2012. The BMP2/7 heterodimer inhibits the human breast cancer stem cell subpopulation and bone metastases formation. Oncogene 31: 21642174.

Cai J, Pardali E, Sánchez-Duffhues G, ten Dijke P. 2012. BMP signaling in vascular diseases. FEBS Lett 586: 1993-2002.
Calva-Cerqueira D, Dahdaleh FS, Woodfield G, Chinnathambi S, Nagy PL, Larsen-Haidle J, Weigel RJ, Howe JR. 2010. Discovery of the BMPR1A promoter and germline mutations that cause juvenile polyposis. Hum Mol Genet 19: 4654-4662.

Celeste AJ, Iannazzi JA, Taylor RC, Hewick RM, Rosen V, Wang EA, Wozney JM. 1990. Identification of transforming growth factor $\beta$ family members present in boneinductive protein purified from bovine bone. Proc Natl Acad Sci 87: 9843-9847.

Chen D, Ji X, Harris MA, Feng JQ, Karsenty G, Celeste AJ, Rosen V, Mundy GR, Harris SE. 1998. Differential roles for bone morphogenetic protein (BMP) receptor type IB and IA in differentiation and specification of mesenchymal precursor cells to osteoblast and adipocyte lineages. J Cell Biol 142: 295-305.

Chen J, Liu J, Yang J, Chen Y, Chen J, Ni S, Song H, Zeng L, Ding K, Pei D. 2011. BMPs functionally replace Klf4 and support efficient reprogramming of mouse fibroblasts by Oct4 alone. Cell Res 21: 205-212.

Cheng H, Jiang W, Phillips FM, Haydon RC, Peng Y, Zhou L, Luu HH, An N, Breyer B, Vanichakarn P, et al. 2003. Osteogenic activity of the fourteen types of human bone morphogenetic proteins (BMPs). J Bone Joint Surg Am 85-A: 1544-1552.

Choi YJ, Kim ST, Park KH, Oh SC, Seo JH, Shin SW, Kim JS, Kim YH. 2012. The serum bone morphogenetic protein2 level in non-small-cell lung cancer patients. Med Oncol 29: $582-588$.

Cunha SI, Pardali E, Thorikay M, Anderberg C, Hawinkels L, Goumans MJ, Seehra J, Heldin CH, ten Dijke P, Pietras K. 2010. Genetic and pharmacological targeting of activin receptor-like kinase 1 impairs tumor growth and angiogenesis. J Exp Med 207: 85-100.

Daluiski A, Engstrand T, Bahamonde ME, Gamer LW, Agius E, Stevenson SL, Cox K, Rosen V, Lyons KM. 2001. Bone morphogenetic protein-3 is a negative regulator of bone density. Nat Genet 27: 84-88.

David L, Mallet C, Mazerbourg S, Feige JJ, Bailly S. 2007. Identification of BMP9 and BMP10 as functional activators of the orphan activin receptor-like kinase 1 (ALK1) in endothelial cells. Blood 109: 1953-1961.

David L, Mallet C, Keramidas M, Lamandé N, Gasc JM, Dupuis-Girod S, Plauchu H, Feige JJ, Bailly S. 2008. Bone morphogenetic protein-9 is a circulating vascular quiescence factor. Circ Res 102: 914-922.

David L, Feige JJ, Bailly S. 2009. Emerging role of bone morphogenetic proteins in angiogenesis. Cytokine Growth Factor Rev 20: 203-212.

Dawson K, Seeman P, Sebald E, King L, Edwards M, Williams J III, Mundlos S, Krakow D. 2006. GDF5 is a second locus for multiple-synostosis syndrome. Am J Hum Genet 78: 708-712.

de Jong DS, Vaes BL, Dechering KJ, Feijen A, Hendriks JM, Wehrens R, Mummery CL, van Zoelen EJ, Olijve W, Steegenga WT. 2004. Identification of novel regulators associated with early-phase osteoblast differentiation. J Bone Miner Res 19: 947-958.

Derynck R, Zhang YE. 2003. Smad-dependent and Smadindependent pathways in TGF- $\beta$ family signalling. $\mathrm{Na}$ ture 425: 577-584. 
Dressler GR. 2006. The cellular basis of kidney development. Annu Rev Cell Dev Biol 22: 509-529.

Ducy P, Zhang R, Geoffroy V, Ridall AL, Karsenty G. 1997. Osf2/Cbfa1: A transcriptional activator of osteoblast differentiation. Cell 89: 747-754.

Dudley AT, Lyons KM, Robertson EJ. 1995. A requirement for bone morphogenetic protein-7 during development of the mammalian kidney and eye. Genes Dev 9: 27952807.

Ebisawa T, Tada K, Kitajima I, Tojo K, Sampath TK, Kawabata M, Miyazono K, Imamura T. 1999. Characterization of bone morphogenetic protein-6 signaling pathways in osteoblast differentiation. J Cell Sci 112: 3519-3527.

Ehata S, Yokoyama Y, Takahashi K, Miyazono K. 2013. Bidirectional roles of bone morphogenetic proteins in cancer: Another molecular Jekyll and Hyde? Pathol Int 63: 287-296.

Fernandez-Lloris R, Vinals F, Lopez-Rovira T, Harley V, Bartrons R, Rosa JL, Ventura F. 2003. Induction of the Sryrelated factor SOX6 contributes to bone morphogenetic protein-2-induced chondroblastic differentiation of C3H10T1/2 cells. Mol Endocrinol 17: 1332-1343.

Fujii M, Takeda K, Imamura T, Aoki H, Sampath TK, Enomoto S, Kawabata M, Kato M, Ichijo H, Iyazono K. 1999. Roles of bone morphogenetic protein type I receptors and Smad proteins in osteoblast and chondroblast differentiation. Mol Biol Cell 10: 3801-3813.

Fujimoto M, Ohte S, Shin M, Yoneyama K, Osawa K, Miyamoto A, Tsukamoto S, Mizuta T, Kokabu S, Machiya A, et al. 2014. Establishment of a novel model of chondrogenesis using murine embryonic stem cells carrying fibrodysplasia ossificans progressiva-associated mutant ALK2. Biochem Biophys Res Commun 455: 347-352.

Fujimoto M, Ohte S, Osawa K, Miyamoto A, Tsukamoto S, Mizuta T, Kokabu S, Suda N, Katagiri T. 2015. Mutant activin-like kinase 2 in fibrodysplasia ossificans progressiva are activated via T203 by BMP type II receptors. Mol Endocrinol 29: 140-152.

Fukuda T, Kanomata K, Nojima J, Kokabu S, Akita M, Ikebuchi K, Jimi E, Komori T, Maruki Y, Matsuoka M, et al. 2008. A unique mutation of ALK2, G356D, found in a patient with fibrodysplasia ossificans progressiva is a moderately activated BMP type I receptor. Biochem Biophys Res Commun 377: 905-909.

Fukuda T, Kohda M, Kanomata K, Nojima J, Nakamura A, Kamizono J, Noguchi Y, Iwakiri K, Kondo T, Kurose J, et al. 2009. Constitutively activated ALK-2 and increased Smad1/ 5 cooperatively induce BMP signaling in fibrodysplasia ossificans progressiva. J Biol Chem 284: 71497156.

Gao H, Chakraborty G, Lee-Lim AP, Mo Q, Decker M, Vonica A, Shen R, Brogi E, Brivanlou AH, Giancotti FG. 2012. The BMP inhibitor Coco reactivates breast cancer cells at lung metastatic sites. Cell 150: 764-779.

Genander M, Cook PJ, Ramsköld D, Keyes BE, Mertz AF, Sandberg R, Fuchs E. 2014. BMP signaling and its pSMAD1 5 target genes differentially regulate hair follicle stem cell lineages. Cell Stem Cell 15: 619-633.

Gong Y, Krakow D, Marcelino J, Wilkin D, Chitayat D, Babul-Hirji R, Hudgins L, Cremers CW, Cremers FP, Brunner HG, et al.1999. Heterozygous mutations in the gene encoding noggin affect human joint morphogenesis. Nat Genet 21: 302-304.

Goumans MJ, Mummery C. 2000. Functional analysis of the TGF- $\beta$ receptor/Smad pathway through gene ablation in mice. Int J Dev Biol 44: 253-265.

Goumans MJ, Valdimarsdottir G, Itoh S, Lebrin F, Larsson J, Mummery C, Karlsson S, ten Dijke P. 2003. Activin receptor-like kinase (ALK) 1 is an antagonistic mediator of lateral TGFß/ALK5 signaling. Mol Cell 12: 817-828.

Greenwald J, Groppe J, Gray P, Wiater E, Kwiatkowski W, Vale W, Choe S. 2003. The BMP7/ActRII extracellular domain complex provides new insights into the cooperative nature of receptor assembly. Mol Cell 11: 605-617.

Griffith DL, Keck PC, Sampath TK, Rueger DC, Carlson WD. 1996. Three-dimensional structure of recombinant human osteogenic protein 1: Structural paradigm for the transforming growth factor $\beta$ superfamily. Proc Natl Acad Sci 93: 878-883.

Grijelmo C, Rodrigue C, Svrcek M, Bruyneel E, Hendrix A, de Wever O, Gespach C. 2007. Proinvasive activity of BMP-7 through SMAD4/src-independent and ERK/ $\mathrm{Rac} / J N K-d e p e n d e n t$ signaling pathways in colon cancer cells. Cell Signal 19: 1722-1732.

Groppe J, Greenwald J, Wiater E, Rodriguez-Leon J, Economides AN, Kwiatkowski W, Affolter M, Vale WW, Belmonte JC, Choe S. 2002. Structural basis of BMP signalling inhibition by the cystine knot protein Noggin. Nature 420: 636-642.

Guo J, Wu G. 2012. The signaling and functions of heterodimeric bone morphogenetic proteins. Cytokine Growth Factor Rev 23: 61-67.

Gustafson B, Hammarstedt A, Hedjazifar S, Hoffmann JM, Svensson PA, Grimsby J, Rondinone C, Smith U. 2015. BMP4 and BMP antagonists regulate human white and beige adipogenesis. Diabetes 64: 1670-1681.

Hackett JA, Surani MA. 2014. Regulatory principles of pluripotency: From the ground state up. Cell Stem Cell 15: 416-430.

Hamasaki M, Hashizume Y, Yamada Y, Katayama T, Hohjoh H, Fusaki N, Nakashima Y, Furuya H, Haga N, Takami Y. 2012. Pathogenic mutation of ALK2 inhibits induced pluripotent stem cell reprogramming and maintenance: Mechanisms of reprogramming and strategy for drug identification. Stem Cells 30: 2437-2449.

Hardwick JC, Van Den Brink GR, Bleuming SA, Ballester I, Van Den Brande JM, Keller JJ, Offerhaus GJ, Van Deventer SJ, Peppelenbosch MP. 2004. Bone morphogenetic protein 2 is expressed by, and acts upon, mature epithelial cells in the colon. Gastroenterology 126: 111-121.

Hatsell SJ, Idone V, Wolken DM, Huang L, Kim HJ, Wang L, Wen X, Nannuru KC, Jimenez J, Xie L, et al. 2015. $A C V R 1^{R 206 H}$ receptor mutation causes fibrodysplasia ossificans progressiva by imparting responsiveness to activin A. Sci Transl Med 7: 303ra137.

Heinke J, Wehofsits L, Zhou Q, Zoeller C, Baar KM, Helbing T, Laib A, Augustin H, Bode C, Patterson C, et al. 2008. BMPER is an endothelial cell regulator and controls bone morphogenetic protein-4-dependent angiogenesis. Circ Res 103: 804-812.

Helms MW, Packeisen J, August C, Schittek B, Boecker W, Brandt BH, Buerger H. 2005. First evidence supporting a potential role for the BMP/SMAD pathway in the pro- 
T. Katagiri and T. Watabe

gression of oestrogen receptor-positive breast cancer J Pathol 206: 366-376.

Hollnagel A, Oehlmann V, Heymer J, Rüther U, Nordheim A. 1999. Id genes are direct targets of bone morphogenetic protein induction in embryonic stem cells. J Biol Chem 278: 19838-19845.

Hong CC, Yu PB. 2009. Applications of small molecule BMP inhibitors in physiology and disease. Cytokine Growth Factor Rev 20: 409-418.

Howe JR, Bair JL, Sayed MG, Anderson ME, Mitros FA, Petersen GM, Velculescu VE, Traverso G, Vogelstein B. 2001. Germline mutations of the gene encoding bone morphogenetic protein receptor $1 \mathrm{~A}$ in juvenile polyposis. Nat Genet 28: 184-187.

Hrusuka KA, Guo G, Wozniak M, Martin D, Miller S, Liapis H, Loveday K, Klahr S, Sampath TK, Morrissey J. 2000. Osteogenic protein-1 prevents renal fibrogenesis associated with ureteral obstruction. Am J Physiol Renal Physio 279: $130-143$.

Hu X, Wang Y, He F, Li L, Zheng Y, Zhang Y, Chen YP. 2012. Noggin is required for early development of murine upper incisors. J Dent Res 91: 394-400.

Ikeda T, Takahashi H, Suzuki A, Ueno N, Yokose S, Yamaguchi A, Yoshiki S. 1996. Cloning of rat type I receptor cDNA for bone morphogenetic protein-2 and bone morphogenetic protein- 4 , and the localization compared with that of the ligands. Dev Dyn 206: 318-329.

Ikeya M, Fukushima K, Kawada M, Onishi S, Furuta Y, Yonemura S, Kitamura T, Nosaka T, Sasai Y. 2010. Cv2, functioning as a pro-BMP factor via twisted gastrulation, is required for early development of nephron precursors. Dev Biol 337: 405-414.

Irie A, Habuchi H, Kimata K, Sanai Y. 2003. Heparan sulfate is required for bone morphogenetic protein-7 signaling. Biochem Biophys Res Commun 308: 858-865.

Ishida W, Hamamoto T, Kusanagi K, Yagi K, Kawabata M, Takehara K, Sampath TK, Kato M, Miyazono K. 2000. Smad6 is a Smad1/5-induced smad inhibitor. Characterization of bone morphogenetic protein-responsive element in the mouse Smad6 promoter. J Biol Chem 275: 6075-6079.

Israel DI, Nove J, Kerns KM, Kaufman RJ, Rosen V, Cox KA, Wozney JM. 1996. Heterodimeric bone morphogenetic proteins show enhanced activity in vitro and in vivo. Growth Factors 13: 291-300.

Itoh F, Watabe T, Miyazono K. 2014. Roles of TGF- $\beta$ family signals in the fate determination of pluripotent stem cells. Semin Cell Dev Biol 32: 98-106.

Jamora C, DasGupta R, Kocieniewski P, Fuchs E. 2003. Links between signal transduction, transcription and adhesion in epithelial bud development. Nature 422: 317-322.

Kameda T, Koike C, Saitoh K, Kuroiwa A, Iba H. 1999. Developmental patterning in chondrocytic cultures by morphogenic gradients: BMP induces expression of Indian hedgehog and Noggin. Genes Cells 4: 175-184.

Kaplan FS. 2013. The skeleton in the closet. Gene 528: 7-11. Karpanen T, Alitalo K. 2008. Molecular biology and pathology of lymphangiogenesis. Annu Rev Pathol 3: 367-397.

Kasai Y, Munne P, Hotta Y, Penttila E, Kavanagh K, Ohbayashi N, Takada S, Thesleff I, Jernvall J, Itoh N. 2005. Reg- ulation of mammalian tooth cusp patterning by ectodin. Science 309: 2067-2070.

Katagiri T. 2010. Heterotopic bone formation induced by bone morphogenetic protein signaling: Fibrodysplasia ossificans progressiva. J Oral Biosci 52: 33-41.

Katagiri T. 2012. Recent topics in fibrodysplasia ossificans progressiva. J Oral Biosci 54: 119-123.

Katagiri T, Yamaguchi A, Komaki M, Abe E, Takahashi N, Ikeda T, Rosen V, Wozney JM, Fujisawa-Sehara A, Suda T. 1994. Bone morphogenetic protein-2 converts the differentiation pathway of $\mathrm{C} 2 \mathrm{C} 12$ myoblasts into the osteoblast lineage. J Cell Biol 127: 1755-1766.

Katagiri T, Boorla S, Frendo JL, Hogan BL, Karsenty G. 1998. Skeletal abnormalities in doubly heterozygous Bmp4 and Bmp7 mice. Dev Genet 22: 340-348.

Katagiri T, Imada M, Yanai T, Suda T, Takahashi N, Kamijo R. 2002. Identification of a BMP-responsive element in Id1, the gene for inhibition of myogenesis. Genes Cells 7: 949-960.

Katsuno Y, Hanyu A, Kanda H, Ishikawa Y, Akiyama F, Iwase T, Ogata E, Ehata S, Miyazono K, Imamura T. 2008. Bone morphogenetic protein signaling enhances invasion and bone metastasis of breast cancer cells through Smad pathway. Oncogene 27: 6322-6333.

Kawai S, Faucheu C, Gallea S, Spinella-Jaegle S, Atfi A, Baron R, Roman SR. 2000. Mouse smad8 phosphorylation downstream of BMP receptors ALK-2, ALK-3, and ALK-6 induces its association with Smad4 and transcriptional activity. Biochem Biophys Res Commun. 271: 682687.

Kessler E, Takahara K, Biniaminov L, Brusel M, Greenspan DS. 1996. Bone morphogenetic protein-1: The type I procollagen C-proteinase. Science 271: 360-362.

Kingsley DM, Bland AE, Grubber JM, Marker PC, Russell LB, Copeland NG, Jenkins NA. 1992. The mouse short ear skeletal morphogenesis locus is associated with defects in a bone morphogenetic member of the TGF- $\beta$ superfamily. Cell 71: 399-410.

Kirsch T, Sebald W, Dreyer MK. 2000. Crystal structure of the BMP-2-BRIA ectodomain complex. Nat Struct Biol 7: 492-496.

Kiyono M, Shibuya M. 2003. Bone morphogenetic protein 4 mediates apoptosis of capillary endothelial cells during rat pupillary membrane regression. $\mathrm{Mol}$ Cell Biol 23: 4627-4636.

Kodach LL, Wiercinska E, de Miranda NF, Bleuming SA, Musler AR, Peppelenbosch MP, Dekker E, van den Brink GR, van Noesel CJ, Morreau H, et al. 2008. The bone morphogenetic protein pathway is inactivated in the majority of sporadic colorectal cancers. Gastroenterology 134: $1332-1341$.

Kokabu S, Gamer L, Cox K, Lowery J, Tsuji K, Raz R, Economides A, Katagiri T, Rosen V. 2012. BMP3 suppresses osteoblast differentiation of bone marrow stromal cells via interaction with Acvr2b. Mol Endocrinol 26: 87-94.

Komaki M, Katagiri T, Suda T. 1996. Bone morphogenetic protein-2 does not alter the differentiation pathway of committed progenitors of osteoblasts and chondroblasts. Cell Tissue Res 284: 9-17.

Korchynskyi O, ten Dijke P. 2002. Identification and functional characterization of distinct critically important 
bone morphogenetic protein-specific response elements in the Id1 promoter. J Biol Chem 277: 4883-4891.

Kowanetz M, Valcourt U, Bergström R, Heldin CH, Moustakas A. 2004. Id2 and Id3 define the potency of cell proliferation and differentiation responses to transforming growth factor $\beta$ and bone morphogenetic protein. Mol Cell Biol 24: 4241-4254.

Kulessa H, Turk G, Hogan BL. 2000. Inhibition of Bmp signaling affects growth and differentiation in the anagen hair follicle. EMBO J 19: 6664-6674.

Laurikkala J, Kasai Y, Pakkasjarvi L, Thesleff I, Itoh N. 2003. Identification of a secreted BMP antagonist, ectodin, integrated BMP, FGF, and SHH signals from the tooth enamel knot. Dev Biol 264: 91-105.

Lee J, Tumbar T. 2012. Hairy tale of signaling in hair follicle development and cycling. Semin Cell Dev Biol 23: $906-$ 916.

Lee J, Son MJ, Woolard K, Donin NM, Li A, Cheng CH, Kotliarova S, Kotliarov Y, Walling J, Ahn S, et al. 2008 Epigenetic-mediated dysfunction of the bone morphogenetic protein pathway inhibits differentiation of glioblastoma-initiating cells. Cancer Cell 13: 69-80.

Lehmann K, Seemann P, Boergermann J, Morin G, Reif S, Knaus P, Mundlos S. 2006. A novel R486Q mutation in $B M P R 1 B$ resulting in either a brachydactyly type $\mathrm{C} / \mathrm{sym}$ phalangism-like phenotype or brachydactyly type A2. Eur J Hum Genet 14: 1248-1254.

Levet S, Ciais D, Merdzhanova G, Mallet C, Zimmers TA, Lee SJ, Navarro FP, Texier I, Feige JJ, Bailly S, et al. 2013 Bone morphogenetic protein 9 (BMP9) controls lymphatic vessel maturation and valve formation. Blood 122: $598-607$.

Li Q, Gu X, Weng H, Ghafoory S, Liu Y, Feng T, Dzieran J, Li L, Ilkavets I, Kruithof-de Julio M, et al. 2013. Bone morphogenetic protein-9 induces epithelial to mesenchymal transition in hepatocellular carcinoma cells. Cancer Sci 104: $398-408$.

Lin J, Patel SR, Cheng X, Cho EA, Levitan I, Ullenbruch M, Phan SH, Park JM, Dressler GR. 2005. Kielin/chordinlike protein, a novel enhancer of BMP signaling, attenuates renal fibrotic disease. Nat Med 11: 387-393.

Lombardo Y, Scopelliti A, Cammareri P, Todaro M, Iovino F, Ricci-Vitiani L, Gulotta G, Dieli F, de Maria R, Stassi G. 2011. Bone morphogenetic protein 4 induces differentiation of colorectal cancer stem cells and increases their response to chemotherapy in mice. Gastroenterology 140: 297-309.

Lopez-Rovira T, Chalaux E, Massagué J, Rosa JL, Ventura F. 2002. Direct binding of Smad1 and Smad4 to two distinct motifs mediates bone morphogenetic protein-specific transcriptional activation of $I d 1$ gene. J Biol Chem 277: 3176-3185.

Lounev VY, Ramachandran R, Wosczyna MN, Yamamoto M, Maidment AD, Shore EM, Glaser DL, Goldhamer DJ, Kaplan FS. 2009. Identification of progenitor cells that contribute to heterotopic skeletogenesis. J Bone Joint Surg Am 91: 652-663.

Luo G, Hofmann C, Bronckers AL, Sohocki M, Bradley A, Karsenty G. 1995. BMP-7 is an inducer of nephrogenesis, and is also required for eye development and skeletal patterning. Genes Dev 9: 2808-2820.
Lyons KM, Pelton RW, Hogan BL. 1989. Patterns of expression of murine Vgr-1 and BMP-2a RNA suggest that transforming growth factor- $\beta$-like genes coordinately regulate aspects of embryonic development. Genes Dev 3: $1657-1668$.

Maddaluno L, Rudini N, Cuttano R, Bravi L, Giampietro C, Corada M, Ferrarini L, Orsenigo F, Papa E, Boulday G, et al. 2013. EndMT contributes to the onset and progression of cerebral cavernous malformations. Nature 498: 492-496.

Maeda S, Hayashi M, Komiya S, Imamura T, Miyazono K. 2004. Endogenous TGF- $\beta$ signaling suppresses maturation of osteoblastic mesenchymal cells. EMBO J 23: 552 563.

Marques G, Musacchio M, Shimell MJ, Wunnenberg-Stapleton K, Cho KW, O'Connor MB. 1997. Production of a DPP activity gradient in the early Drosophila embryo through the opposing actions of the SOG and TLD proteins. Cell 91: 417-426.

Mayeur C, Lohmeyer LK, Leyton P, Kao SM, Pappas AE, Kolodziej SA, Spagnolli E, Yu B, Galdos RL, Yu PB, et al. 2014. The type I BMP receptor Alk3 is required for the induction of hepatic hepcidin gene expression by interleukin-6. Blood 123: 2261-2268.

Mazerbourg S, Klein C, Roh J, Kaivo-Oja N, Mottershead DG, Korchynskyi O, Ritvos O, Hsueh AJ. 2004. Growth differentiation factor-9 signaling is mediated by the type I receptor, activin receptor-like kinase 5. Mol Endocrinol 18: $653-665$.

McPherron AC, Lawler AM, Lee SJ. 1999. Regulation of anterior/posterior patterning of the axial skeleton by growth/differentiation factor 11. Nat Genet 22: 260-264.

Medici D, Shore EM, Lounev VY, Kaplan FS, Kalluri R, Olsen BR. 2010. Conversion of vascular endothelial cells into multipotent stem-like cells. Nat Med 16: 1400-1406.

Miyama K, Yamada G, Yamamoto TS, Takagi C, Miyado K, Sakai M, Ueno N, Shibuya H. 1999. A BMP-inducible gene, $d l x 5$, regulates osteoblast differentiation and mesoderm induction. Dev Biol 208: 123-133.

Miyazaki H, Watabe T, Kitamura T, Miyazono K. 2004. BMP signals inhibit proliferation and in vivo tumor growth of androgen-insensitive prostate carcinoma cells. Oncogene 23: 9326-9335.

Miyazono K, Kamiya Y, Morikawa M. 2010. Bone morphogenetic protein receptors and signal transduction. J Biochem 147: 35-51.

Mohedas AH, Xing X, Armstrong KA, Bullock AN, Cuny GD, Yu PB. 2013. Development of an ALK2-biased BMP type I receptor kinase inhibitor. ACS Chem 8: 1291-1302.

Morikawa M, Koinuma D, Miyazono K, Heldin CH. 2013. Genome-wide mechanisms of Smad binding. Oncogene 32: $1609-1615$.

Moser M, Binder O, Wu Y, Aitsebaomo J, Ren R, Bode C, Bautch VL, Conlon FL, Patterson C. 2003. BMPER, a novel endothelial cell precursor-derived protein, antagonizes bone morphogenetic protein signaling and endothelial cell differentiation. Mol Cell Biol 23: 5664-5579.

Murashima-Suginami A, Takahashi K, Sakata T, Tsukamoto H, Sugai M, Yanagita M, Shimizu A, Sakurai T, Slavkin HC, Bessho K. 2008. Enhanced BMP signaling results in supernumerary tooth formation in USAG-1 deficient mouse. Biochem Biophys Res Commun 369: 1012-1016. 
Nakase T, Nomura S, Yoshikawa H, Hashimoto J, Hirota S, Kitamura Y, Oikawa S, Ono K, Takaoka K. 1994. Transient and localized expression of bone morphogenetic protein 4 messenger RNA during fracture healing. J Bone Miner Res 9: 651-659.

Nakashima K, Zhou X, Kunkel G, Zhang Z, Deng JM, Behringer RR, de Crombrugghe B. 2002. The novel zinc finger-containing transcription factor osterix is required for osteoblast differentiation and bone formation. Cell 108: $17-29$.

Nakayama N, Duryea D, Manoukian R, Chow G, Han CY 2003. Macroscopic cartilage formation with embryonic stem-cell-derived mesodermal progenitor cells. J Cell Sci 116: $2015-2028$.

Nam D, Guo B, Chatteriee S, Chen MH, Nelson D, Yechoor VK, Ma K. 2015. The adipocyte clock controls brown adipogenesis through the TGF- $\beta$ and BMP signaling pathways. J Cell Sci 128: 1835-1847.

Nelsen SM, Christian JL. 2009. Site-specific cleavage of BMP4 by furin, PC6, and PC7. J Biol Chem 284: 27157-27166.

Niessen K, Zhang G, Ridgway JB, Chen H, Yan M. 2010. ALK1 signaling regulates early postnatal lymphatic vessel development. Blood 115: 1654-1661.

Nili M, Shinde U, Rotwein P. 2010. Soluble repulsive guidance molecule $\mathrm{c}$ /hemojuvelin is a broad spectrum bone morphogenetic protein (BMP) antagonist and inhibits both BMP2- and BMP6-mediated signaling and gene expression. J Biol Chem 285: 24783-24792.

Nishimori H, Ehata S, Suzuki HI, Katsuno Y, Miyazono K. 2012. Prostate cancer cells and bone stromal cells mutually interact with each other through bone morphogenetic protein-mediated signals. J Biol Chem 287: $20037-$ 20046.

Nishinakamura R, Sakaguchi M. 2014. BMP signaling and its modifiers in kidney development. Pediatr Nephrol 29: 681-686.

Nishitoh H, Ichijo H, Kimura M, Matsumoto T, Makishima F, Yamaguchi A, Yamashita H, Enomoto S, Miyazono K. 1996. Identification of type I and type II serine/threonine kinase receptors for growth/differentiation factor-5. J Biol Chem 271: 21345-21352.

Nojima J, Kanomata K, Takada Y, Fukuda T, Kokabu S, Ohte S, Takada T, Tsukui T, Yamamoto TS, Sasanuma H, et al. 2010. Dual roles of Smad proteins in the conversion from myoblasts to osteoblastic cells by bone morphogenetic proteins. J Biol Chem 285: 15577-15586.

Onichtchouk D, Chen YG, Dosch R, Gawantka V, Delius H, Massagué J, Niehrs C. 1999. Silencing of TGF- $\beta$ signalling by the pseudoreceptor BAMBI. Nature 401: 480485.

Özkaynak E, Rueger DC, Drier EA, Corbett C, Ridge RJ, Sampath TK, Oppermann H. 1990. OP-1 cDNA encodes an osteogenic protein in the TGF- $\beta$ family. EMBO J 9: 2085-2093.

Özkaynak E, Schnegelsberg PN, Jin DF, Clifford GM, Warren FD, Drier EA, Oppermann H. 1992. Osteogenic protein-2. A new member of the transforming growth factor$\beta$ superfamily expressed early in embryogenesis. J Biol Chem 267: 25220-25227.

Pacifici M, Shore EM. 2016. Common mutations in ALK2/ ACVR1, a multi-faceted receptor, have roles in distinct pediatric musculoskeletal and neural orphan disorders. Cytokine Growth Factor Rev 27: 93-104.

Padgett RW, Wozney JM, Gelbart WM. 1993. Human BMP sequences can confer normal dorsal-ventral patterning in the Drosophila embryo. Proc Natl Acad Sci 90: 29052909.

Papanikolaou G, Samuels ME, Ludwig EH, MacDonald ML, Franchini PL, Dubé MP, Andres L, MacFarlane J, Sakellaropoulos N, Politou M, et al. 2004. Mutations in HFE2 cause iron overload in chromosome 1q-linked juvenile hemochromatosis. Nat Genet 36: 77-82.

Park SW, Hur SY, Yoo NJ, Lee SH. 2010. Somatic frameshift mutations of bone morphogenic protein receptor 2 gene in gastric and colorectal cancers with microsatellite instability. APMIS 118: 824-829.

Pereira RC, Economides AN, Canalis E. 2000. Bone morphogenetic proteins induce gremlin, a protein that limits their activity in osteoblasts. Endocrinology 141: 45584563.

Piccirillo SG, Reynolds BA, Zanetti N, Lamorte G, Binda E, Broggi G, Brem H, Olivi A, Dimeco F, Vescovi AL. 2006. Bone morphogenetic proteins inhibit the tumorigenic potential of human brain tumour-initiating cells. Nature 444: 761-765.

Piccolo S, Agius E, Lu B, Goodman S, Dale L, De Robertis EM. 1997. Cleavage of Chordin by Xolloid metalloprotease suggests a role for proteolytic processing in the regulation of Spemann organizer activity. Cell 91: 407416.

Pickup MW, Hover LD, Polikowsky ER, Chytil A, Gorska AE, Novitskiy SV, Moses HL, Owens P. 2015. BMPR2 loss in fibroblasts promotes mammary carcinoma metastasis via increased inflammation. Mol Oncol 9: 179-191.

Polinkovsky A, Robin NH, Thomas JT, Irons M, Lynn A, Goodman FR, Reardon W, Kant SG, Brunner HG, van der Burgt I, et al. 1997. Mutations in CDMP1 cause autosomal dominant brachydactyly type C. Nat Genet 17: $18-19$.

Ricard N, Ciais D, Levet S, Subileau M, Mallet C, Zimmers TA, Lee SJ, Bidart M, Feige JJ, Bailly S. 2012. BMP9 and BMP10 are critical for postnatal retinal vascular remodeling. Blood 119: 6162-6171.

Rosenzweig BL, Imamura T, Okadome T, Cox GN, Yamashita H, ten Dijke P, Heldin CH, Miyazono K. 1995. Cloning and characterization of a human type II receptor for bone morphogenetic proteins. Proc Natl Acad Sci 92: $7632-7636$.

Rothhammer T, Poser I, Soncin F, Bataille F, Moser M, Bosserhoff AK. 2005. Bone morphogenic proteins are overexpressed in malignant melanoma and promote cell invasion and migration. Cancer Res 65: 448-456.

Ruppert R, Hoffmann E, Sebald W. 1996. Human bone morphogenetic protein 2 contains a heparin-binding site which modifies its biological activity. Eur J Biochem 237: 295-302.

Samad TA, Rebbapragada A, Bell E, Zhang Y, Sidis Y, Jeong SJ, Campagna JA, Perusini S, Fabrizio DA, Schneyer AL, et al. 2005. DRAGON, a bone morphogenetic protein coreceptor. J Biol Chem 280: 14122-14129.

Samavarchi-Tehrani P, Golipour A, David L, Sung HK, Beyer TA, Datti A, Woltjen K, Nagy A, Wrana JL. 2010. Functional genomics reveals a BMP-driven mesenchymal-to- 
epithelial transition in the initiation of somatic cell reprogramming. Cell Stem Cell 7: 64-77.

Sampath TK, Reddi AH. 1983. Homology of bone-inductive proteins from human, monkey, bovine, and rat extracellular matrix. Proc Natl Acad Sci 80: 6591-6595.

Sampath TK, Coughlin JE, Whetstone RM, Banach D, Corbett C, Ridge RJ, Özkaynak E, Oppermann H, Rueger DC. 1990. Bovine osteogenic protein is composed of dimers of OP-1 and BMP-2A, two members of the transforming growth factor- $\beta$ superfamily. J Biol Chem 265: 13198-13205.

Sampath TK, Maliakal JC, Hauschka PV, Jones WK, Sasak $\mathrm{H}$, Tucker RF, White KH, Coughlin JE, Tucker MM, Pang RHL, et al. 1992. Recombinant human osteogenic protein-1 (hOP-1) induces new bone formation in vivo with a specific activity comparable with natural bovine osteogenic protein and stimulates osteoblast proliferation and differentiation in vitro. J Biol Chem 267: 20352-20362.

Sampath TK, Rashka KE, Doctor JS, Tucker RF, Hoffmann FM. 1993. Drosophila transforming growth factor $\beta$ superfamily proteins induce endochondral bone formation in mammals. Proc Natl Acad Sci 90: 6004-6008.

Sanvitale CE, Kerr G, Chaikuad A, Ramel MC, Mohedas AH, Reichert S, Wang Y, Triffitt JT, Cuny GD, Yu PB, et al. 2013. A new class of small molecule inhibitor of BMP signaling. PLoS ONE 8: e62721.

Sartori R, Schirwis E, Blaauw B, Bortolanza S, Zhao J, Enzo E, Stantzou A, Mouisel E, Toniolo L, Ferry A, et al. 2013. BMP signaling controls muscle mass. Nat Genet 45: 1309-1318.

Scharpfenecker M, van Dinther M, Liu Z, van Bezooijen RL, Zhao Q, Pukac L, Löwik CW, ten Dijke P. 2007. BMP-9 signals via ALK1 and inhibits bFGF-induced endothelial cell proliferation and VEGF-stimulated angiogenesis. $J$ Cell Sci 120: 964-972.

Schreuder H, Liesum A, Pohl J, Kruse M, Koyama M. 2005. Crystal structure of recombinant human growth and differentiation factor 5: Evidence for interaction of the type I and type II receptor-binding sites. Biochem Biophys Res Commun 329: 1076-1086.

Seemann P, Schwappacher R, Kjaer KW, Krakow D, Lehmann K, Dawson K, Stricker S, Pohl J, Ploger F, Staub E, et al. 2005. Activating and deactivating mutations in the receptor interaction site of GDF5 cause symphalangism or brachydactyly type A2. J Clin Invest 115: 23732381.

Senn N. 1889. Senn on the healing of aseptic bone cavities by implantation of antiseptic decalcified bone. Ann Surg 10: $352-368$.

Settle SH Jr, Rountree RB, Sinha A, Thacker A, Higgins K, Kingsley DM. 2003. Multiple joint and skeletal patterning defects caused by single and double mutations in the mouse Gdf6 and Gdf5 genes. Dev Biol 254: 116-130.

Shafritz AB, Shore EM, Gannon FH, Zasloff MA, Taub R, Muenke M, Kaplan FS. 1996. Overexpression of an osteogenic morphogen in fibrodysplasia ossificans progressiva. $N$ Engl J Med 335: 555-561.

Shen Q, Little SC, Xu M, Haupt J, Ast C, Katagiri T, Mundlos S, Seemann P, Kaplan FS, Mullins MC, et al. 2009. The fibrodysplasia ossificans progressiva R206H ACVR1 mutation activates BMP-independent chondrogenesis and zebrafish embryo ventralization. J Clin Invest 119: $3462-3472$.

Shin M, Ohte S, Fukuda T, Sasanuma H, Yoneyama K, Kokabu S, Miyamoto A, Tsukamoto S, Hohjoh H, Jimi E, et al. 2013. Identification of a novel bone morphogenetic protein (BMP)-inducible transcript, BMP-inducible transcript-1, by utilizing the conserved BMP-responsive elements in the Id genes. J Bone Miner Metab 31: 34-43.

Shirai YT, Ehata S, Yashiro M, Yanagihara K, Hirakawa K, Miyazono K. 2011. Bone morphogenetic protein-2 and -4 play tumor suppressive roles in human diffuse-type gastric carcinoma. Am J Pathol 179: 2920-2930.

Solloway MJ, Dudley AT, Bikoff EK, Lyons KM, Hogan BL, Robertson EJ. 1998. Mice lacking Bmp6 function. Dev Genet 22: 321-339.

Steinbicker AU, Sachidanandan C, Vonner AJ, Yusuf RZ, Deng DY, Lai CS, Rauwerdink KM, Winn JC, Saez B, Cook CM, et al. 2011. Inhibition of bone morphogenetic protein signaling attenuates anemia associated with inflammation. Blood 117: 4915-4923.

Storm EE, Huynh TV, Copeland NG, Jenkins NA, Kingsley DM, Lee SJ. 1994. Limb alterations in brachypodism mice due to mutations in a new member of the TGF $\beta$-superfamily. Nature 368: 639-643.

Sugimoto H, LeBleu VS, Bosukonda D, Keck P, Taduri G, Bechtel W, Okada H, Carlson W Jr, Bey P, Rusckowski M, et al. 2012. Activin-like kinase 3 is important for kidney regeneration and reversal of fibrosis. Nat Med 18: 396404.

Suzuki A, Kaneko E, Maeda J, Ueno N. 1997. Mesoderm induction by BMP- 4 and -7 heterodimers. Biochem Biophys Res Commun 232: 153-156.

Suzuki Y, Montagne K, Nishihara A, Watabe T, Miyazono K. 2008. BMPs promote proliferation and migration of endothelial cells via stimulation of VEGF-A/VEGFR2 and angiopoietin-1/Tie2 signalling. J Biochem 143: 199-206.

Suzuki Y, Ohga N, Morishita Y, Hida K, Miyazono K, Watabe T. 2010. BMP-9 induces proliferation of multiple types of endothelial cells in vitro and in vivo. J Cell Sci 123: 16841692.

Takada T, Katagiri T, Ifuku M, Morimura N, Kobayashi M, Hasegawa K, Ogamo A, Kamijo R. 2003. Sulfated polysaccharides enhance the biological activities of bone morphogenetic proteins. J Biol Chem 278: 43229-43235.

Takahashi K, Yamanaka S. 2006. Induction of pluripotent stem cells from mouse embryonic and adult fibroblast cultures by defined factors. Cell 126: 663-676.

Takahashi K, Tanabe K, Ohnuki M, Narita M, Ichisaka T, Tomoda K, Yamanaka S. 2007. Induction of pluripotent stem cells from adult human fibroblasts by defined factors. Cell 131: 861-872.

Takase M, Imamura T, Sampath TK, Takeda K, Ichijo H, Miyazono K, Kawabata M. 1998. Induction of Smad6 mRNA by bone morphogenetic proteins. Biochem Biophys Res Commun 244: 26-29.

ten Dijke P, Yamashita H, Sampath TK, Reddi AH, Estevez M, Riddle DL, Ichijo H, Heldin CH, Miyazono K. 1994. Identification of type I receptors for osteogenic protein-1 and bone morphogenetic protein-4. J Biol Chem 269: 16985-16988. 
Thomas JT, Kilpatrick MW, Lin K, Erlacher L, Lembessis P, Costa T, Tsipouras P, Luyten FP. 1997. Disruption of human limb morphogenesis by a dominant negative mutation in CDMP1. Nat Genet 17: 58-64.

Truksa J, Peng H, Lee P, Beutler E. 2006. Bone morphogenetic proteins 2, 4, and 9 stimulate murine hepcidin 1 expression independently of Hfe, transferrin receptor 2 (Tfr2), and IL-6. Proc Natl Acad Sci 103: 10289-10293.

Tseng YH, Kokkotou E, Schulz TJ, Huang TL, Winnay JN, Tran TT, Suzuki R, Espinoza DO, Yamamoto Y, Ahrens MJ, et al. 2008. New role of bone morphogenetic protein 7 in brown adipogenesis and energy expenditure. Nature 454: 1000-1004.

Tsugawa D, Oya Y, Masuzaki R, Ray K, Engers DW, Dib M, Do N, Kuramitsu K, Ho K, Frist A, et al. 2014. Specific activin receptor-like kinase 3 inhibitors enhance liver regeneration. J Pharmacol Exp Ther 351: 549-558.

Tsukamoto S, Mizuta T, Fujimoto M, Ohte S, Osawa K, Miyamoto A, Yoneyama K, Murata E, Machiya A, Jimi E, et al. 2014. Smad9 is a new type of transcriptional regulator in bone morphogenetic protein signaling. Sci Rep 4: 7596.

Tsumaki N, Tanaka K, Arikawa-Hirasawa E, Nakase T, Kimura T, Thomas JT, Ochi T, Luyten FP, Yamada Y. 1999. Role of CDMP-1 in skeletal morphogenesis: Promotion of mesenchymal cell recruitment and chondrocyte differentiation. J Cell Biol 144: 161-173.

Tucker AS, Al Khamis A, Sharpe PT. 1998a. Interactions between Bmp-4 and Msx-1 act to restrict gene expression to odontogenic mesenchyme. Dev Dyn 212: 533-539.

Tucker AS, Matthews KL, Sharpe PT. 1998b. Transformation of tooth type induced by inhibition of BMP signaling. Science 282: 1136-1138.

Tumbar T, Guasch G, Greco V, Blanpain C, Lowry WE Rendl M, Fuchs E. 2004. Defining the epithelial stem cell niche in skin. Science 303: 359-363.

Urist MR. 1965. Bone: Formation by autoinduction. Science 150: 893-899.

Urist MR, Strates BS. 1971. Bone morphogenetic protein. J Dent Res 50: 1392-1406.

Vainio S, Karavanova I, Jowett A, Thesleff I. 1993. Identification of BMP-4 as a signal mediating secondary induction between epithelial and mesenchymal tissues during early tooth development. Cell 75: 45-58.

Valdimarsdottir G, Goumans MJ, Rosendahl A, Brugman M, Itoh S, Lebrin F, Sideras P, ten Dijke P. 2002. Stimulation of Id 1 expression by bone morphogenetic protein is sufficient and necessary for bone morphogenetic protein-induced activation of endothelial cells. Circulation 106: $2263-2270$

Voorneveld PW, Stache V, Jacobs RJ, Smolders E, Sitters AI, Liesker A, Korkmaz KS, Lam SM, De Miranda NF, Morreau H, et al. 2013. Reduced expression of bone morphogenetic protein receptor IA in pancreatic cancer is associated with a poor prognosis. Br J Cancer 109: 1805-1812.

Voorneveld PW, Kodach LL, Jacobs RJ, van Noesel CJ, Peppelenbosch MP, Korkmaz KS, Molendijk I, Dekker E, Morreau H, van Pelt GW, et al. 2015. The BMP pathway either enhances or inhibits the Wnt pathway depending on the SMAD4 and p53 status in CRC. Br J Cancer 112: $122-130$.
Vukicevic S, Basic V, Rogic D, Basic N, Shih MS, Shepard A, Jin D, Dattatreymamurty B, Jones W, Dorai H, et al. 1998. Osteogenic protein-1 (bone morphogenetic protein-7) reduces severity of injury after ischemic acute renal failure in rat. J Clin Invest 102: 202-214.

Wang EA, Rosen V, Cordes P, Hewick RM, Kriz MJ, Luxenberg DP, Sibley BS, Wozney JM. 1988. Purification and characterization of other distinct bone-inducing factors. Proc Natl Acad Sci 85: 9484-9488.

Wang EA, Rosen V, D’Alessandro JS, Bauduy M, Cordes P, Harada T, Israel DI, Hewick RM, Kerns KM, LaPan P. 1990. Recombinant human bone morphogenetic protein induces bone formation. Proc Natl Acad Sci 87: 2220 2224.

Wang EA, Israel DI, Kelly S, Luxenberg DP. 1993. Bone morphogenetic protein- 2 causes commitment and differentiation in C3H10T1/ 2 cells and 3T3 cells. Growth Factors 9: $57-71$.

Wang XP, Suomalainen M, Jorgez CJ, Matzuk MM, Werner S, Thesleff I. 2004. Follistatin regulates enamel patterning in mouse incisors by asymmetrically inhibiting BMP signaling and ameloblast differentiation. Dev Cell 7: 719730.

Wang RH, Li C, Xu X, Zheng Y, Xiao C, Zerfas P, Cooperman S, Eckhaus M, Rouault T, Mishra L, et al. 2005. A role of SMAD4 in iron metabolism through the positive regulation of hepcidin expression. Cell Metab 2: 399-409.

Wang Y, Li L, Zheng Y, Yuan G, Yang G, He F, Chen Y. 2012. BMP activity is required for tooth development from the lamina to bud stage. J Dent Res 91: 690-695.

Wang Z, Shen Z, Li Z, Duan J, Fu S, Liu Z, Bai H, Zhang Z, Zhao J, Wang X, et al. 2015. Activation of the BMPBMPR pathway conferred resistance to EGFR-TKIs in lung squamous cell carcinoma patients with EGFR mutations. Proc Natl Acad Sci 112: 9990-9995.

Whittle AJ, Carobbio S, Martins L, Slawik M, Hondares E, Vazquez MJ, Morgan D, Cslkasz RI, Gallego R, Rodriguez-Cuenca S, et al. 2012. BMP8b increases brown adipose tissue thermogenesis through both central and peripheral actions. Cell 49: 871-885.

Wiley DM, Jin SW. 2011. Bone morphogenetic protein functions as a context-dependent angiogenic cue in vertebrates. Semin Cell Dev Biol 22: 1012-1018

Winbanks CE, Chen JL, Qian H, Liu Y, Bernardo BC, Beyer C, Watt KI, Thomson RE, Connor T, Turner BJ, et al. 2013. The bone morphogenetic protein axis is a positive regulator of skeletal muscle mass. J Cell Biol 203: 345357.

Wolfman NM, Hattersley G, Cox K, Celeste AJ, Nelson R, Yamaji N, Dube JL, DiBlasio-Smith E, Nove J, Song JJ, et al. 1997. Ectopic induction of tendon and ligament in rats by growth and differentiation factors 5,6 , and 7 , members of the TGF- $\beta$ gene family. J Clin Invest 100: $321-330$.

Wosczyna MN, Biswas AA, Cogswell CA, Goldhamer DJ. 2012. Multipotent progenitors resident in the skeletal muscle interstitium exhibit robust BMP-dependent osteogenic activity and mediate heterotopic ossification. J Bone Miner Res 27: 1004-1017.

Wozney JM, Rosen V, Celeste AJ, Mitsock LM, Whitters MJ, Kriz RW, Hewick RM, Wang EA. 1988. Novel regulators 
of bone formation: Molecular clones and activities. Science 242: $1528-1534$.

Xiao YT, Xiang LX, Shao JZ. 2007. Bone morphogenetic protein. Biochem Biophys Res Commun 362: 550-553.

Xu SC, Harris MA, Rubenstein JL, Mundy GR, Harris SE. 2001. Bone morphogenetic protein-2 (BMP-2) signaling to the Col2 $\alpha 1$ gene in chondroblasts requires the homeobox gene Dlx-2. DNA Cell Biol 20: 359-365.

Yanagita M, Oka M, Watanabe T, Iguchi H, Niida A, Takahashi S, Akiyama T, Miyazono K, Yanagisawa M, Sakurai T. 2004. USAG-1, a bone morphogenetic protein antagonist abundantly expressed in the kidney. Biochem Biophys Res Commun 316: 490-500.

Yanagita M, Okuda T, Endo S, Tanaka M, Takahashi K, Sugiyama F, Kunita S, Takahashi S, Fukatsu A, Yanagisawa $\mathrm{M}$, et al. 2006. Uterine sensitization-associated gene-1 (USAG-1), a novel BMP antagonist expressed in the kidney, accelerates tubular injury. J Clin Invest 116: 70-79.

Yang S, Zhong C, Frenkel B, Reddi AH, Roy-Burman P. 2005. Diverse biological effect and Smad signaling of bone morphogenetic protein 7 in prostate tumor cells. Cancer Res 65: 5769-5777.

Yang Z, Hai B, Qin L, Ti X, Shangguan L, Zhao Y, Wiggins L, Liu Y, Feng JQ, Chang JY, et al. 2013. Cessation of epithelial Bmp signaling switches the differentiation of crown epithelia to the root lineage in a $\beta$-catenin-dependent manner. Mol Cell Biol 33: 4732-4744.

Ying QL, Nichols J, Chambers I, Smith A. 2003. BMP induction of Id proteins suppresses differentiation and sustains embryonic stem cell self-renewal in collaboration with STAT3. Cell 115: 281-292.

Ying QL, Wray J, Nichols J, Batlle-Morera L, Doble B, Woodgett J, Cohen P, Smith A. 2008. The ground state of embryonic stem cell self-renewal. Nature 453: 519-523.

Yoshimatsu Y, Lee YG, Akatsu Y, Taguchi L, Suzuki HI, Cunha SI, Maruyama K, Suzuki Y, Yamazaki T, Katsura A, et al. 2013. Bone morphogenetic protein-9 inhibits lymphatic vessel formation via activin receptor-like kinase 1 during development and cancer progression. Proc Natl Acad Sci 110: 18940-18945.
Yu PB, Beppu H, Kawai N, Li E, Bloch KD. 2005. BMP type II receptor deletion reveals BMP ligand-specific gain of signaling in pulmonary artery smooth muscle cells. J Biol Chem 280: 24443-24450.

Yu PB, Deng DY, Lai CS, Hong CC, Cuny GD, Bouxsein ML, Hong DW, McManus PM, Katagiri T, Sachidanandan C, et al. 2008a. BMP type I receptor inhibition reduces heterotopic ossification. Nat Med 14: 1363-1369.

Yu PB, Hong CC, Sachidanandan C, Babitt JL, Deng DY, Hoyng SA, Lin HY, Bloch KD, Peterson RT. 2008b. Dorsomorphin inhibits BMP signals required for embryogenesis and iron metabolism. Nat Chem Biol 4: 33-41.

Yuan S, Pan Q, Liu W, Wu B, Han X, Bi Z. 2011. Recombinant BMP $4 / 7$ fusion protein induces differentiation of bone marrow stem cells. J Cell Biochem 112: 3054-3060.

Zeisberg M, Bottiglio C, Kumar N, Maeshima Y, Strutz F, Muller GA, Kalluri R. 2003. BMP-7 counteracts TGF- $\beta 1$ induced epithelial-to-mesenchymal transition and reverses chronic renal injury. Nat Med 9: 964-967.

Zhang Z, Song Y, Zhao X, Zhang X, Fermin C, Chen Y. 2002. Rescue of cleft palate in Msxl-deficient mice by transgenic Bmp4 reveals a network of BMP and Shh signaling in the regulation of mammalian palatogenesis. Development 129: 4135-4146.

Zhang D, Schwarz EM, Rosier RN, Zuscik MJ, Puzas JE, O'Keefe RJ. 2003. ALK2 functions as a BMP type I receptor and induces Indian hedgehog in chondrocytes during skeletal development. J Bone Miner Res 18: 1593-1604.

Zhang L, Sun H, Zhao F, Lu P, Ge C, Li H, Hou H, Yan M, Chen T, Jiang G, et al. 2012. BMP4 administration induces differentiation of $\mathrm{CD}_{133^{+}}$hepatic cancer stem cells, blocking their contributions to hepatocellular carcinoma. Cancer Res 72: 4276-4285.

Zhou XP, Woodford-Richens K, Lehtonen R, Kurose K, Aldred M, Hampel H, Launonen V, Virta S, Pilarski R, Salovaara R, et al. 2001. Germline mutations in BMPR1A/ALK3 cause a subset of cases of juvenile polyposis syndrome and of Cowden and Bannayan-RileyRuvalcaba syndromes. Am J Hum Genet 69: 704-711. 


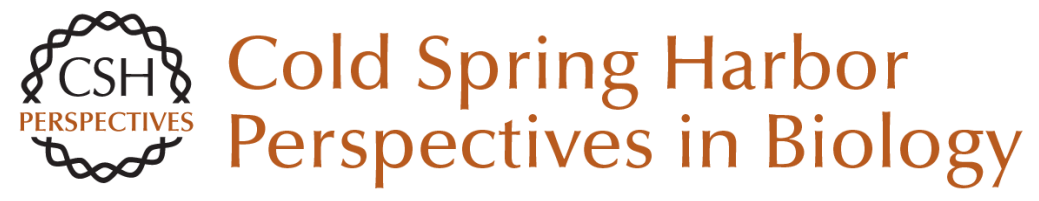

\section{Bone Morphogenetic Proteins}

Takenobu Katagiri and Tetsuro Watabe

Cold Spring Harb Perspect Biol 2016; doi: 10.1101/cshperspect.a021899

Subject Collection The Biology of the TGF-\&\#946; Family

TGF- $\beta$ Family Signaling in Early Vertebrate

Development

Joseph Zinski, Benjamin Tajer and Mary C. Mullins

Bone Morphogenetic Protein-Based Therapeutic Approaches

Jonathan W. Lowery and Vicki Rosen

TGF- $\beta$ Family Signaling in Ductal Differentiation and Branching Morphogenesis

Kaoru Kahata, Varun Maturi and Aristidis Moustakas

TGF- $\beta$ Signaling in Control of Cardiovascular Function

Marie-José Goumans and Peter ten Dijke

TGF- $\beta$ Family Signaling in Tumor Suppression and Cancer Progression Joan Seoane and Roger R. Gomis

Targeting TGF- $\beta$ Signaling for Therapeutic Gain Rosemary J. Akhurst

Regulation of Hematopoiesis and Hematological Disease by TGF- $\beta$ Family Signaling Molecules Kazuhito Naka and Atsushi Hirao

TGF- $\beta$ Family Signaling in Neural and Neuronal Differentiation, Development, and Function Emily A. Meyers and John A. Kessler
TGF- $\beta$ Family Signaling in Mesenchymal

Differentiation

Ingo Grafe, Stefanie Alexander, Jonathan $R$. Peterson, et al.

TGF- $\beta 1$ Signaling and Tissue Fibrosis Kevin K. Kim, Dean Sheppard and Harold A. Chapman

Bone Morphogenetic Proteins in Vascular Homeostasis and Disease

Marie-José Goumans, An Zwijsen, Peter ten Dijke, et al.

TGF- $\beta$ Family Signaling in Epithelial

Differentiation and Epithelial-Mesenchymal

Transition

Kaoru Kahata, Mahsa Shahidi Dadras and Aristidis Moustakas

TGF- $\beta$ Family Signaling in Connective Tissue and

Skeletal Diseases

Elena Gallo MacFarlane, Julia Haupt, Harry C.

Dietz, et al.

The TGF- $\beta$ Family in the Reproductive Tract

Diana Monsivais, Martin M. Matzuk and Stephanie

A. Pangas

TGF- $\beta$ Family Signaling in Drosophila Ambuj Upadhyay, Lindsay Moss-Taylor, Myung-Jun Kim, et al.

Signaling Cross Talk between TGF- $\beta /$ Smad and Other Signaling Pathways Kunxin Luo

For additional articles in this collection, see http://cshperspectives.cshlp.org/cgi/collection/

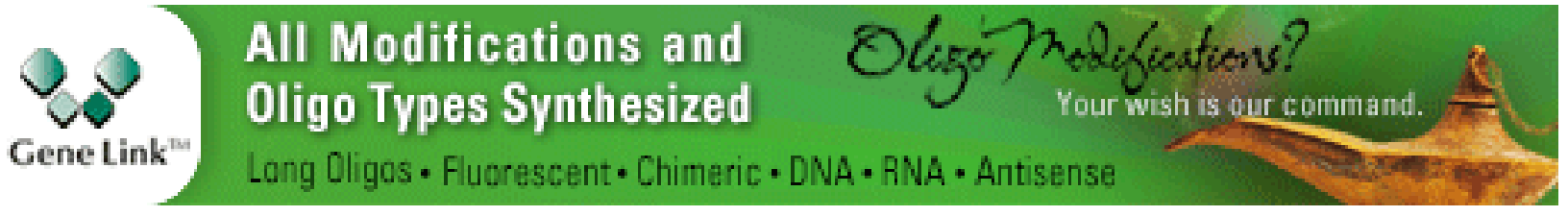


For additional articles in this collection, see http://cshperspectives.cshlp.org/cgi/collection/

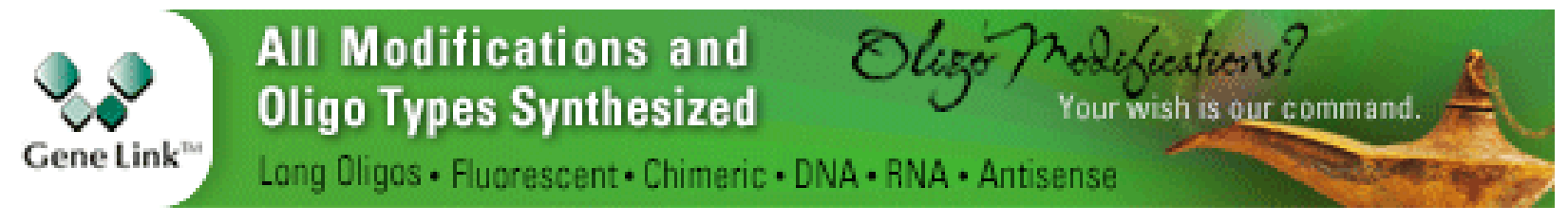

Copyright @ 2016 Cold Spring Harbor Laboratory Press; all rights reserved 